\title{
Techno-Economic Assessment of Renewable Hybrid Systems for Rural Electrification and Distributed Generation in Selected Sites across Nigeria
}

\author{
Ajayi, Oluseyi. $\mathrm{O}^{1}$, Ohijeagbon ${\mathrm{O} . \mathrm{D}^{2}, \text { Ajanaku, K.O }}^{3}$, Aasa, S.A $\mathrm{A}^{1}$ and Omotosho, $0 . \mathrm{A}^{1}$ \\ ${ }^{1}$ Mechanical Engineering Department, Covenant University, Ota, Nigeria \\ ${ }^{2}$ Mechanical Engineering Department, University of Lagos, Akoka, Lagos, Nigeria \\ ${ }^{3}$ Chemistry Department, Covenant University, Ota, Nigeria
}

Received date: 1 October 2013; Accepted date: 23 August 2014; Published date: 2 June 2015

Academic Editor: Dorel Ailenei

Correspondence should be addressed to: Ajayi, Oluseyi. O; oluseyi.ajayi@covenantuniversity.edu.ng

Copyright (C 2015. Ajayi, Oluseyi. O, Ohijeagbon O.D, Ajanaku, K.O, Aasa, S.A and Omotosho, O. A. Distributed under Creative Commons CC-BY 4.0

\begin{abstract}
The study considered the potentials and economic feasibility of solar and wind energy resources for rural-electricity and distributed generation from six selected sites of Nigeria. Remote communities cut off from the central grid and made up of 200 homes, a school and health centre were conceived - a site per geopolitical zone was investigated. A specific electrical load profile was then developed to suite the rural communities. In view of this, the design that will optimally meet a daily load demand with 1\% LOLP was carried out by considering standalone PV, Wind and Diesel systems design, as well as a Wind-PV hybrid system design. Further to this, an analysis covering the same sites was carried out to determine the commercial viability of generating and distributing electricity in the Megawatt range via distributed generation. The 24 years' (19872010) solar, wind and other meteorological data utilized in this study was obtained from the Nigeria meteorological centre, Oshodi. The results of the study revealed that wind standalone system is the most economically viable substitute for power generation at most of the sites with costs ranged between $\$ 0.129 / \mathrm{kWh}$ and $\$ 0.327 / \mathrm{kWh}$ for Jos and Benin City respectively. More so, a huge potential for profit making by willing investors in line with the present tariff order for wind and PV distributed generation was discovered with all sites being viable on both configuration. The optimum LCOE for distributed generation ranged between $-\$ 0.021 / \mathrm{kWh}$ and $\$ 0.158 / \mathrm{kWh}$ for PV distributed generation in Iseyin and Maiduguri respectively. This is very much competitive with grid electricity. Thus, renewable electricity could be adopted and included into the federal rural development strategy, thereby reducing the energy deficit being experienced in Nigeria.
\end{abstract}

Keywords: Photovoltaic Power; Wind power; Solar-Wind Hybrid; Distributed Generation; Cost per kWh; Clean Energy; Nigeria

Cite this Article as: Ajayi, Oluseyi. O, Ohijeagbon O.D, Ajanaku, K.O, Aasa, S.A and Omotosho, O. A (2015),

"“Techno-Economic Assessment of Renewable Hybrid Systems for Rural Electrification and Distributed Generation in Selected Sites across Nigeria," Journal of African Research in Business \& Technology, Vol. 2015 (2015), Article ID 124767, DOI: 10.5171/2015.124767 


\section{Introduction}

Access to modern energy supply is requisite to sustainable development. However, a population of about 1.3 billion people worldwide are deprived of access to electricity and over 2.6 billion people worldwide rely on traditional biomass for cooking and heating. More so, between 2011 and 2013, access to sustainable electricity generation remained static in growth rate. Although, some countries like those of the Latin America and certain Asia made great leaps forward, other regions fell largely behind, with India regressing in the number of people with access to electricity by 17 million. Half of the world's population without access to electricity reside on the African continent (Renewables Global Status Report, 2014)

In most remote communities of developing nations, connection to the central electric grid is usually prohibitive due to its noneconomic viability. Moreover, the major use of energy in these rural communities is for heating and cooking purposes. Such energy resources are derived from repeated biomass burning. The byproducts of such burning have been found to be deleterious to both humans and the environment. Based on this, renewable energy systems (RES) present an exceptional prospect to hasten the transition from deleterious biomass based energy supply to modern energy services in remote and rural areas. It has the potential of escalating access to sustainable energy for cooking and heating, inexpensive lighting, communications, food preservation, improved public health, and also for agro-processing and other productive activities.

The conventional electrical power system model in use in Nigeria involves a system that mainly revolves around centrally generated electrical power and a massive system of transmission and distribution networks. Albeit, this system has been in use for many decades and the shortcomings associated with these model has led to economic volatility as well as diverse threats to public health (Walker, 2008; Wustenhagen, et al 2007; Rogers et al, 2008; Bayod-Rujula, 2009; Clark \& Eisenberg,
2008). Moreover, the conventional systems are decrepit and outmoded, ineffective, and regularly strained, resulting in high utility fee variations payable by the general public (Ipakchi and Albuyeh, 2009; Mamo et al, 2009). Thus, to gradually shift emphasis from centrally generated electricity that operate on deleterious fossil based generation systems to RES, there would be the need to establish and strengthen institutional, financial, legal, and regulatory support mechanisms for renewable energy deployment must. Once established, these mechanisms will help improve access to financing, growth in necessary infrastructure, and increased awareness about renewable energy.

Some of these mechanisms have been put in place in Nigeria. One notable policy thrust, is the positive feed-in tariff law on wind and solar electricity enabling. It enables consumers deliver additional green energy to a mini-grid network at prices higher than that of network electricity (Ohijeagbon and Ajayi, 2015). The regulation describes a form of generation where excess renewable energy generated by a consumer above the 1 MW mark may be sold to a nearby minigrid system at prices higher than grid electricity. These feed-in tariffs are captured under provisions for embedded (distributed) generation as presented in the multi-year tariff order for 20122017(Nigerian Electricity Regulatory Commission, 2012; Overview of the NERC regulations, 2012). Therefore, willing investors may take advantage of this regulation in order to provide cheap access to electricity at rural communities and also help to meet the Millennium Development Goals (MDGs) while also sustaining themselves as profitable ventures through proceeds from sales to a mini-grid in proximity of the rural communities.

Therefore, this study offers a design approach that will establish the potentials and economic feasibility of solar and wind resources for rural-electricity and distributed generation for six selected sites of Nigeria. A site per geopolitical zone was considered. Rural communities unconnected to the national grid and made up of 200 homes, a school and health centre 
were considered. A specific electrical load profile was then developed to suite the rural communities. Further to this, an analysis covering the same sites was carried out to determine the commercial feasibility of generating and distributing electricity in the Megawatt range via distributed generation.

\section{Potential of Renewable Energy Resources in Nigeria}

A number of indigenous researchers have studied the potential of Renewable Energy (RE) resources in Nigeria in view of demonstrating their viability in the country. Onyebuchi (1989) projected the technical potential of solar energy in Nigeria by means of a device with $5 \%$ conversion efficiency. The study concluded that $15.0 \times 10^{14} \mathrm{~kJ}$ of useful energy can be generated annually. Chineke et al. (2008) disclosed that Nigeria receives copious supply of solar energy that can be valuably harvested. The yearly average daily solar radiation was evaluated to $5.25 \mathrm{kWh} / \mathrm{m}^{2}$ day, with specific values ranged between $3.5 \mathrm{~kW} \mathrm{~h} / \mathrm{m}^{2}$-day, in the coastal regions of the south and $7.0 \mathrm{kWh} / \mathrm{m}^{2}$-day at the northern boundaries. Mean duration of sunshine hours within the country was estimated at 6.5 hours with yearly average solar energy intensity being $1,935 \mathrm{kWh}$ per $\mathrm{m}^{2}$ per year, which approximately equals $1,770 \mathrm{TWh}$ of solar energy retrievable on a yearly basis. This is roughly equivalent to a multiple of 120,000 of the total annual average electrical energy produced by the Power Holding Company of Nigeria (PHCN) prior to privatization (UNDP, 2012). It is therefore reasonable to integrate solar energy in the nation's energy mix.

A number of research reports present the potentials for wind-to-electricity projects in Nigeria. For instance, Adekoya and Adewale (1992) looked into wind speed data of 30 stations in Nigeria and found the annual mean wind speeds and power flux densities to fluctuate between $1.5-4.1 \mathrm{~m} / \mathrm{s}$ and $5.7-22.5 \mathrm{~W} / \mathrm{m}^{2}$ respectively. Fagbenle and Karayiannis (1994) also studied the 10year wind data from 1979 to 1988 taking into cognizance surface and higher winds as well as upper limit of guts. Ajayi (2010) hinted that inland, the wind is superlative in mountainous regions of the North, while moorland topographies of the middle belt and northern precincts of the nation have enormous prospect for massive wind energy production. Mean wind speeds in the north and south were revealed to lie between $4.0-7.5 \mathrm{~m} / \mathrm{s}$ and $3.0-3.5 \mathrm{~m} / \mathrm{s}$ respectively at $10 \mathrm{~m}$ height. In view of the above, most researchers concluded that wind energy is principally of excelent abundance in core northern states, the hilly and mountainous parts of the central and eastern states, and also the country's offshore areas (Adekoya et al, 1992; Ajayi, 2010; Fagbenle, et al, 2011; Ajayi et al, 2011; Ajayi et al, 2010).

These information points to the fact that, Nigeria is richly endowed with huge natural supply of solar and wind energy resources and has good prospect for improved sustainable electricity production. Nonetheless, the energy need of the populace in remote areas is still centered on traditional biomass (Ajayi et al, 2010) because this group of fuels have been discovered to supply more than $50 \%$ of total energy usage in Nigeria (National Energy Policy, 2003). In furtherance to this, the disparity in fuel wood supply and demand in many remote locations is now a threat to the energy security of these communities (Kanase-Patil et al, 2010; Rajoriya, 2010; Setiawan et al, 2009; Akella et al, 2007; Promoting Renewable Energy, 2007) due to the present degree of deforestation. It is a fact that Nigeria parades one of the poorest annual per capita consumption of electricity worldwide, which is estimated to fall between $100 \mathrm{kWh}$ and $135 \mathrm{kWh}$ (Ajayi and Ajayi, 2013) with a sizeable proportion of her population still unconnected to the national electricity grid (Ajayi, 2010). Hence, a diversification of the nation's energy mix is cogent if the country is to achieve its target of energy security by the year 2020. This is with the clear understanding that RE resources has the advantage of being employed as a standalone facility besides its potential for grid connectivity.

\section{Present Work}

In Nigeria, only a few research studies subsist depicting the prospect of hybrid RE system for power generation (Nwosu et al, 
2012; Mbakwe et al, 2011; Abatcha et al,2011; Agajelu et al, 2013). These were also only focused on small scale generation for remote telecom applications and also for individual buildings. Research studies on the design and economic viability of hybrid systems that can provide sustainable power for remote communities are uncommon. More so, those that capture distributed generation analyeis for potentially viable sites in Nigeria are very rare. Part of these includes the study by Ohijeagbon \& Ajayi (2014). It focused the prospect and economic viability of standalone hybrid systems for rural community utilization and distributed generation at a site in Northwest Nigeria. The results revealed that distributed generation was viable for wind and PV systems rated above $7.5 \mathrm{MW}$ in Sokoto. This study therefore focused on the techno-economic assessment of hybrid RE for rural electrification and distributed generation in six selected sites across the geopolitical zones of Nigeria. The sites are spread across the country.

\section{Methodology and Data Collection}

\section{Data Collection}

The twenty-four years (1987 - 2010) daily global solar radiation, daily wind speed data, sunshine hours, minimum and maximum air temperature, and minimum and maximum relative humidity that were employed for this research were supplied by the Nigeria Meteorological agency (NIMET), Oshodi, Lagos, Nigeria. The solar radiation data employed for a few of the sites were consequent upon the model proposed by (Ajayi et al, 2014). This was as a result of inadequate data for some sites. The location parameters of the selected sites are as presented in Table 1. Wind turbines ranging from two to four $25 \mathrm{~kW}$ turbines, with single $3 \mathrm{MW}$ turbines in series were optimally designed for community utilization and distributed generation respectively. The cumulative solar panels employed ranged between $105 \mathrm{~kW} \& 190$ $\mathrm{kW}$ for community utilization with optimal solar arrays ranged between 25MW $35 \mathrm{MW}$ for distributed generation. A diesel generator of $35 \mathrm{~kW}$ was utilized for the study covering conventional power systems for the communities. An econometric analysis of the diesel system is presented in Table 2.

RETScreen ${ }^{\circledR}$ software was used as a feasibility tool. This software receives average air temperature and relative humidity, which is significant, owing to the dependence of PV module efficiency on close by air temperature and relative humidity (RETScreen 4 Software, 2013; Omubo-Pepple et al, 2013; Skoplaki et al, 2009; Fesharaki, 2011). Also, most cell types show evidence of a reduction in efficiency as their temperature rises, while an increase in relative humidity has been found to act in such a way as to diminish the magnitude of solar radiation retrievable (Hedzlin et al, 2009; Ettah et al, 2012; Hussein et al, 2013).

Table 1: Location Parameter of the Studied Sites (Ajayi Et Al., 2014)

\begin{tabular}{llllrr} 
S/N & Geopolitical Zone & State & Sites & Latitude $\left({ }^{\circ} \mathbf{N}\right)$ & Longitude $\left({ }^{\circ} \mathbf{E}\right)$ \\
\hline 1 & North West (NW) & Kano & Kano & 12.0031 & 8.5288 \\
2 & North East (NE) & Borno & Maiduguri & 11.8333 & 13.1500 \\
3 & North Central (NC) & Plateau & Jos & 9.9167 & 8.9000 \\
4 & South West (SW) & Oyo & Iseyin & 7.9667 & 3.6000 \\
5 & South East (SE) & Enugu & Enugu & 6.4500 & 7.5000 \\
6 & South-South (SS) & Edo & Benin City & 6.3176 & 5.6145 \\
\hline
\end{tabular}


Table 2: Diesel System Econometrics for Nigeria (Rural Community Utilization) (Ajayi Et Al., 2014)

\begin{tabular}{lllllll}
\hline All Sites & $\begin{array}{l}\text { Total NPC } \\
\mathbf{( \$ )}\end{array}$ & $\begin{array}{l}\text { Total NPC } \\
\text { (NGN) }\end{array}$ & $\begin{array}{l}\text { Initial } \\
\text { Capital } \\
\mathbf{( \$ )}\end{array}$ & $\begin{array}{l}\text { Initial Capital } \\
\text { (NGN) }\end{array}$ & $\begin{array}{l}\text { LCOE } \\
\text { (\$) }\end{array}$ & $\begin{array}{l}\text { LCOE } \\
\text { (NGN) }\end{array}$ \\
\hline Diesel Generator & $1,033,203$ & $160,146,465$ & $\$ 12,250$ & $1,898,750$ & $\$ 0.619$ & 95.95 \\
Diesel With Battery & 781,259 & $121,095,145$ & $\$ 31,000$ & $4,805,000$ & $\$ 0.469$ & 72.70 \\
\hline
\end{tabular}

\section{Load Calculation}

Load profiles for rural and remote communities should not be merely assumed, but must be well analyzed. Notwithstanding, they have been discovered to be a far below those of urban communities. A number of researchers discovered that characteristically on the average, 1 $\mathrm{kWh} /$ day per home is required in rural community homes (Clean Energy Project, 2005; Lambert et al, 2006). Nonetheless, for the intention of this study, the energy

\begin{abstract}
demand requirement of the rural communities were developed based on individual power rating of each appliance generally utilized in each home as presented in Table 3 and 4 (General Wattage Chart, 2013; How much electricity, 2013; RETScreen 4 Software, 2013; Ohijeagbon and Ajayi, 2014; Ajayi et al., 2014)). Consequently, each home is estimated to consume as $1.4 \mathrm{kWh} /$ day, based on the analysis of Tables 3 and 4, with a calculated primary peak load value of $46 \mathrm{~kW}$. Fig. 1 presents the 24 hours hourly load profile for the communities.
\end{abstract}

Table 3: General Wattage Chart for Some Household Appliances (Ohijeagbon and Ajayi, 2014; Ajayi Et Al., 2014)

\begin{tabular}{ll}
\hline Power rating & Household Appliance \\
\hline 24 watts & $42 "$ ceiling fan (low speed) \\
$55-90$ watts & $19 "$ CRT television \\
$150-340$ watts & Desktop Computer \& 17" CRT monitor \\
60 watts & 60 -watt light bulb (incandescent) \\
18 watts & CFL light bulb (60-watt equivalent)
\end{tabular}


Table 4: Electricity Consumption Analysis for a Rural Community of 200 Homes (Ohijeagbon and Ajayi, 2014; Ajayi Et Al., 2014)

\begin{tabular}{|c|c|c|c|c|c|c|c|}
\hline Description & AC/DC & $\begin{array}{l}\text { Intermittent } \\
\text { resource-load } \\
\text { correlation }\end{array}$ & $\begin{array}{l}\text { Base case } \\
\text { load/home } \\
\text { (watt) }\end{array}$ & $\begin{array}{l}\text { No. of } \\
\text { appliance } \\
\text { per } \\
\text { home(watt) }\end{array}$ & $\begin{array}{l}\text { Hours of } \\
\text { use per } \\
\text { day } \\
\text { (hr/day) }\end{array}$ & $\begin{array}{l}\text { Days of } \\
\text { use per } \\
\text { week }\end{array}$ & $\begin{array}{l}\text { Base case } \\
\text { load for } \\
\text { community } \\
\text { (watt) }\end{array}$ \\
\hline TV & $\mathrm{AC}$ & Negative & 90 & 1 & 6 & 7 & 18000 \\
\hline Bulb & $\mathrm{AC}$ & Negative & 18 & 6 & 7 & 7 & 21600 \\
\hline Fan & $\mathrm{AC}$ & Zero & 24 & 3 & 8 & 7 & 14400 \\
\hline & & & Community & Community & & & \\
\hline Water Pump & $\mathrm{AC}$ & Positive & based & based & 3 & 3 & 20000 \\
\hline Radio & DC & Zero & 6 & 1 & 5 & 7 & 1200 \\
\hline Clinic & & & Community & Community & & & \\
\hline equipment & $\mathrm{AC}$ & Positive & based & based & 5 & 5 & 2000 \\
\hline School & & & Community & Community & & & \\
\hline & $\mathrm{AC}$ & Positive & based & based & 5 & 5 & 2400 \\
\hline Electricity & & & & & & & \\
\hline daily - $\mathrm{AC}$ & & & & & & & \\
\hline (KWh) & & & & \multicolumn{3}{|c|}{ Electricity - daily - AC (KWh) } & 357.256571 \\
\hline
\end{tabular}

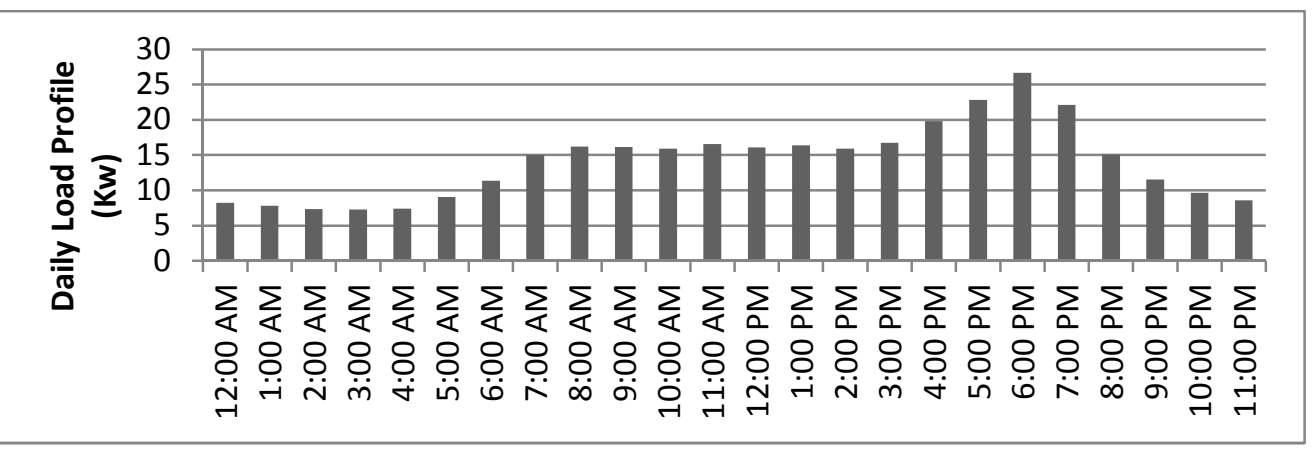

Fig 1: Average Daily Load Profile Used for Design of Hybrid Energy Systems in Rural Areas of Nigeria (Ohijeagbon and Ajayi, 2014; Ajayi Et Al., 2014)

\section{Modeling the Photovoltaic (PV) Project}

Description of the solar radiation algorithm

The solar radiation algorithm utilized is described as a progression of three basic steps presented in the figure below (see Figure 2) (Ohijeagbon and Ajayi, 2014; Ajayi et al., 2014): 


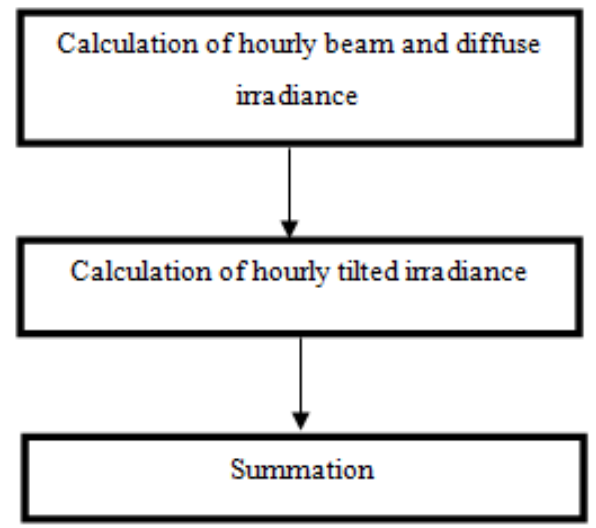

Figure 2: Flowchart for Tilted Irradiance Calculation

\section{Calculation of Hourly Global and Diffuse Irradiance}

Solar radiation can be considered to be of two parts: beam radiation, and diffuse radiation. Therefore, the tilting algorithm utilized, uses the knowledge of beam and diffuse radiation for every hour of an average day.

\section{PV Array Model}

The model created by Evans served as the PV array model (Evans, 1981).

\section{Modeling the Wind Speed Distribution}

\section{Wind Energy Model}

Since weibull probability density function (WPDF) has been found to significantly fit with experimental long-term distribution for various sites (Ajayi et al, 2011), the wind speed profile characterization and analysis for each site was carried out using the WPDF.

\section{Cost Benefit Analysis}

Economics plays a critical role in selecting potential energy sources. Renewable and non-renewable energy sources have proven to be very diverse in cost characteristics. Renewable sources are usually higher in initial capital costs and low in operating costs, while conventional non-renewable sources usually tend to be vice-versa. The life-cycle cost (or NPC) analysis consists of, costs of initial construction, component replacements, maintenance, fuel, cost of buying power from the grid, and miscellaneous costs. On the other hand, revenues include, income retrieved from sales to the grid, in addition to any salvage value occurring at the end of the project lifetime. When evaluating the NPC, costs are taken as positive and revenues are seen as negative. Therefore, a negative NPC value signifies a net present value (NPV).

The annualized cost for each component is made up of, the capital, replacement, maintenance, and fuel costs, as well as salvage value and other costs or revenues. Further to this, the annualized costs are summed for each component, plus any miscellaneous costs, thus resulting in the total annualized cost of the system.

The total net present cost is:

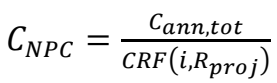

where: $C_{\text {ann,tot }}=$ total annualized cost, $R_{\text {proj }}$ the project lifetime, and $\operatorname{CRF}(\bullet)$ is the capital recovery factor, given by the equation:

$C R F(i, N)=\frac{i(1+i)^{N}}{(1+i)^{N}-1}$

where, $\mathrm{i}$, is the annual real interest rate (the discount rate) and $\mathrm{N}$ is the number of years.

The annualized capital cost of each component is evaluated as follows:

$C_{\text {acap }}=C_{\text {cap }} \cdot \operatorname{CRF}\left(i, R_{\text {proj }}\right)$ 
where:

$C_{c a p}=$ initial capital cost of the component

To determine the annualized replacement cost of a system component, the salvage value at the end of the project lifetime is subtracted from the annualized value of all replacement costs that occurred throughout the lifetime. It is noteworthy that the annualized replacement cost may be negative since it includes the annualized salvage value.

Each component's annualized replacement cost is evaluated as follows:

$C_{\text {arep }}=C_{\text {rep }} \cdot f_{\text {rep }} . S F F\left(i, R_{\text {comp }}\right)-$ $\operatorname{S.SFF}\left(i, R_{\text {comp }}\right)$

$f_{r e p}$, is a factor that takes into account the fact that the component lifetime can be different from the project lifetime:

$$
f_{\text {rep }}=\left\{\begin{array}{rr}
C R F\left(i, R_{\text {proj }}\right) / C R F\left(i, R_{\text {rep }}\right), & R_{\text {rep }}>0 \\
0, & R_{\text {rep }}=0
\end{array}\right\}
$$

$R_{\text {rep }}$, the duration of replacement cost, is given by:

$R_{\text {rep }}=R_{\text {comp }} \cdot I N T\left(\frac{R_{p r o j}}{R_{c o m p}}\right)$

Where, INT ( ) is the integer function, that returns the integer part of a real value.

The salvage value $S$ of each component is given by:

$S=C_{\text {rep }} \cdot \frac{R_{\text {rem }}}{R_{\text {comp }}}$

$R_{\text {rem }}$, is the remaining life of the component at the end of the project lifetime:

$R_{\text {rem }}=R_{\text {comp }}-\left(R_{\text {proj }}-R_{\text {rep }}\right)$

$C_{r e p}=$ replacement cost of the component.

SFF ( ) = sinking fund factor

$R_{\text {comp }}=$ lifetime of the component

The sinking fund factor is a ratio used to calculate the future value of a series of equal annual cash flows and it is given as;
$\operatorname{SFF}(i, N)=\frac{i}{(1+i)^{N}-1}$

The total O\&M cost is a sum that comprises of: the system fixed O\&M cost, any penalty for capacity shortage and penalty for emissions (if any).

The total annual $0 \& \mathrm{M}$ cost is given as:

$C_{\text {om,total }}=C_{\text {om,fixed }}+C_{c s}+C_{\text {emissions }}$

where:

$C_{\text {om,fixed }}=$ system fixed $0 \& \mathrm{M} \operatorname{cost}(\$ / \mathrm{yr})$

$C_{c s}=$ the penalty for capacity shortage $(\$ / \mathrm{yr})$

$C_{\text {emissions }}=$ the penalty for emissions $(\$ / \mathrm{yr})$

The capacity shortage is calculated using the following equation:

$C_{c S}=c_{c S} \cdot E_{c S}$

where:

$c_{c S}=$ capacity shortage penalty $(\$ / \mathrm{kWh})$

$E_{c s}=$ total capacity shortage $(\mathrm{kWh} / \mathrm{yr})$

Therefore, the total annualized cost is:

$C_{a n n, t o t}=C_{a c a p, t o t a l}+C_{\text {arep }, \text { total }}+C_{\text {om,total }}$

$+R_{\text {ann }, \text { proj }}$

Where, $R_{\text {ann,proj }}=$ annual project revenue (\$/yr)

The levelised cost of energy (LCOE) is therefore:

$L C O E=\frac{C_{\text {ann }, \text { tot }}}{E_{\text {prim }}+E_{\text {def }}+E_{\text {grid,sales }}}$

Where, $C_{a n n, t o t}$ is the total annualized cost, $E_{\text {prim }}$ and $E_{\text {def }}$ are the total amounts of primary and deferrable load, respectively, that the system serves per year, and $E_{\text {grid,sales }}$ is the amount of energy sold to the grid per year. 


\section{Specifications of Wind Turbines and Solar Panel Used in this Study}

PGE turbines (HOMER Software, 2013) were cumulatively utilized for this research to study the wind standalone system (WSS), each having the specification indicated in Table 6, while the Enercon turbine is employed for edistributed generation.

It is noteworthy that when revenues from the project far surpasses other incurred costs, i.e. $C_{\text {om,total }}$ (the annual operating cost of the project), and the summation of $\left(C_{\text {acap,total }}+C_{\text {arep,total }}\right)$. It results in a negative total annualized cost, that reflects in a negative LCOE which is termed levelised value of energy (LVOE) (Ohijeagbon \& Ajayi, 2015); which reveals the profitability of the project from an investors' stance. Hence,

$(-L C O E)=\frac{-C_{\text {ann,tot }}}{E_{\text {prim }}+E_{\text {def }}+E_{\text {grid,sales }}}=L V O E$

Table 6: Turbine Specification (Ajayi et al., 2014)

\begin{tabular}{|c|c|c|c|c|c|c|c|}
\hline $\begin{array}{l}\text { Wind } \\
\text { Machine }\end{array}$ & $\begin{array}{l}V_{c} \\
(\mathrm{~m} / \mathrm{s}) \\
\end{array}$ & $\begin{array}{l}V_{F i} \\
(\mathrm{~m} / \mathrm{s}) \\
\end{array}$ & $\begin{array}{l}V_{F o} \\
(\mathrm{~m} / \mathrm{s}) \\
\end{array}$ & $\begin{array}{l}V_{R} \\
(\mathrm{~m} / \mathrm{s}) \\
\end{array}$ & $\begin{array}{l}P_{\text {eR }} \\
(\mathrm{kW}) \\
\end{array}$ & $\begin{array}{l}\text { Available } \\
\text { Hub } \\
\text { Height } \\
\text { (m) }\end{array}$ & $\begin{array}{l}\text { Rotor } \\
\text { Diameter } \\
\text { (m) }\end{array}$ \\
\hline $\begin{array}{l}\text { PGE } \\
20 / 25\end{array}$ & 3.5 & 1.7 & 25 & 9 & 25 & $24 / 30 / 36$ & 20 \\
\hline Enercon & 3 & 2 & 25 & 12 & 3000 & $120 / 135$ & 101 \\
\hline
\end{tabular}

where: $\mathrm{V}_{\mathrm{c}}=$ cut-in wind speed, $\mathrm{V}_{\mathrm{Fi}}=$ low wind cut-out speed, $\mathrm{V}_{\mathrm{Fo}}=$ high wind cut-out speed, $\mathrm{V}_{\mathrm{R}}=$ rated wind speed, $\mathrm{P}_{\mathrm{eR}}=$ rated power at rated wind speed.

Table 7 presents the solar panel specification used in this research with a collector area of $5.1 \mathrm{~m}^{2}$ rated at $1 \mathrm{~kW}$ by
Sunpower. Consequently, in order to match the load demand, the solar collector area increases while other parameters in Table 7 remained constant (RETScreen 4 Software, 2013). Table 8 presents each components' cost with their installation costs embedded used in designing the Hybrid Energy Systems (HES).

Table 7: PV System Specification (Ajayi Et Al., 2014)

\begin{tabular}{|c|c|c|c|c|c|c|c|}
\hline $\begin{array}{l}\text { PV } \\
\text { Technology }\end{array}$ & $\begin{array}{l}\text { Power } \\
\text { capacity }\end{array}$ & Efficiency & NOCT & $\begin{array}{l}\text { Temperature } \\
\text { coefficient }\end{array}$ & $\begin{array}{l}\text { Solar } \\
\text { collector } \\
\text { area }\end{array}$ & $\begin{array}{l}\text { Miscellaneous } \\
\text { losses }\end{array}$ & $\begin{array}{l}\text { Array } \\
\text { slope } \\
\text { angle } \\
\end{array}$ \\
\hline mono-Si & $1 \mathrm{~kW}$ & $19.60 \%$ & $45^{\circ} \mathrm{C}$ & $0.40 \% /{ }^{\circ} \mathrm{C}$ & $5.1 \mathrm{~m}^{2}$ & $10 \%$ & $\begin{array}{l}\text { Location } \\
\text { latitude }\end{array}$ \\
\hline
\end{tabular}

Table 8: Cost of Components Used in the Design of HES (Installation Cost Embedded in Component Cost) (Ajayi et al., 2014)

\begin{tabular}{|c|c|c|c|c|c|}
\hline Component & $\begin{array}{l}\text { Interest } \\
\text { Rate (\%) }\end{array}$ & Project Life time & Cost $(\$ / \mathbf{k W})$ & $0 \& M(\$)$ & $\begin{array}{l}\text { Replacement } \\
\text { Cost }(\$ / \mathbf{k W})\end{array}$ \\
\hline Wind turbine & 6 & 20 years & 1800 & $400 / y r$ & 1800 \\
\hline Solar panel & 6 & 25 years & 3000 & $0 / \mathrm{yr}$ & 1500 \\
\hline Battery & 6 & 10 years (float) & 100 & $20 / y r$ & 100 \\
\hline $\begin{array}{l}\text { Converter } \\
\text { Diesel }\end{array}$ & 6 & 12 years & 500 & $80 / y r$ & 500 \\
\hline generator & 6 & $15,000 \mathrm{hrs}$ & 350 & $0.050 / \mathrm{hr}$ & 300 \\
\hline
\end{tabular}




\section{Results and Discussion}

Fig. 3 shows the average monthly solar radiation profiles for a period spanning between 1987 and 2010. The figure reveals that the 24 years monthly average solar radiation varied between $2.93\left(\mathrm{kWh} / \mathrm{m}^{2} / \mathrm{d}\right)$ in August for Iseyin (SW) and 6.468
$\left(\mathrm{kWh} / \mathrm{m}^{2} / \mathrm{d}\right)$ in April for Maiduguri (NE). More so, the period between July and August experienced the lowest solar radiation across the sites/states. Looking through the analyzed data, Maiduguri and Kano were found to be the sites/states with the superior solar profiles.

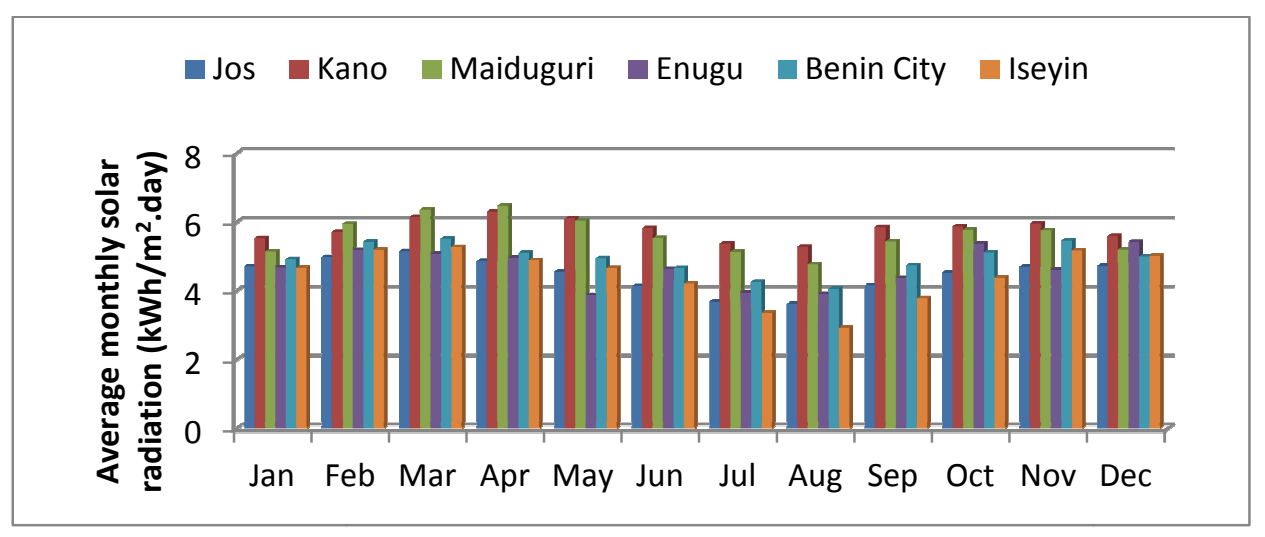

Fig 3: 24- Year Monthly Average Radiation (Kwh/ $\mathrm{M}^{2}$-Day) for Sites in Nigeria

Fig. 4 reveals the average yearly solar radiation profiles for the period covering 1987 and 2010. Maiduguri (NE) is observed to have the highest yearly average radiation in 1997, while Enugu (SE) had the lowest in 2004. It was also discovered that the monthly solar data varied much more than the yearly solar radiation data. Further to this, Fig. 4 shows that the solar radiation profiles for all sites in Nigeria can be grouped broadly in two, namely; Northern Nigeria and Southern Nigeria, with very related characteristics within each group. The similarity in characteristics is a result of similar weather and climatic conditions within the same geographical region.
Taking into consideration the hours equaled or exceeded for a series of mean measured solar radiation (Fig. 5) across the studied period, the study revealed that the corresponding power generated for each site from the designed PV array is between about $49.2 \%-51.1 \%$ of the hourly duration in a whole year. This however is due to solar radiation occurring only at daytime, unlike wind speed. Hence, Iseyin has a twenty four year average sunshine daily duration of about 5.46 hours, while Jos has 7.33 hours. 


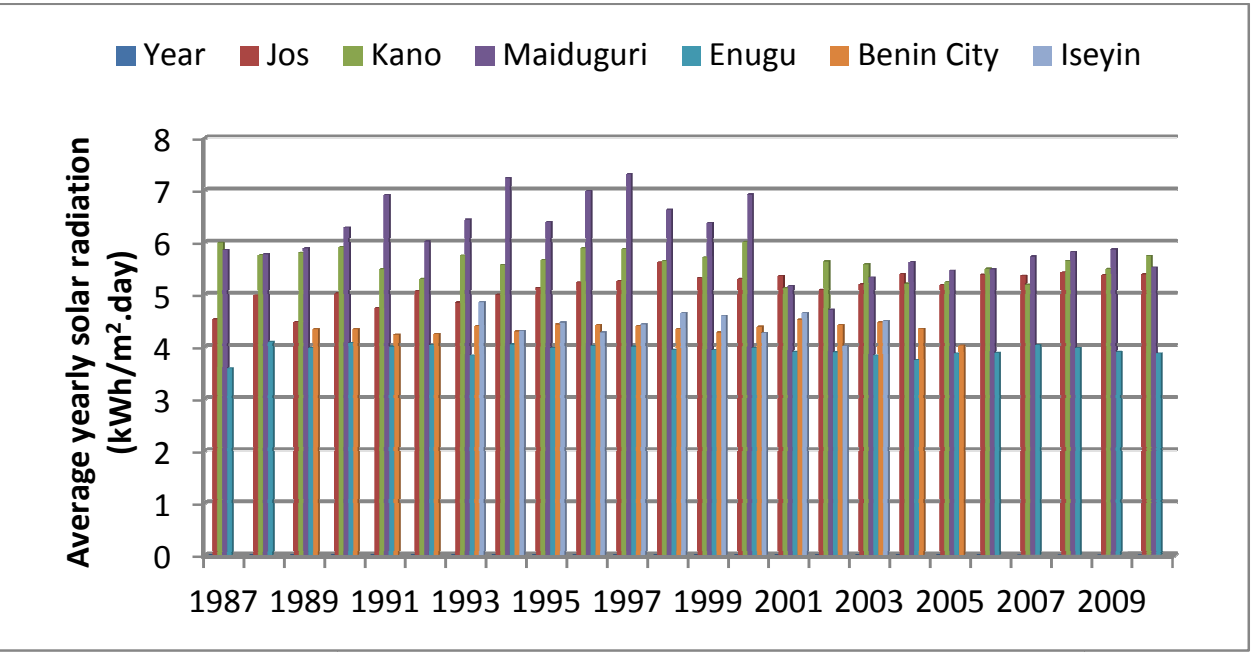

Fig 4: 24- Year Yearly Average Radiation $\left(\mathrm{kWh} / \mathrm{m}^{2}\right.$-day) for Sites in Nigeria

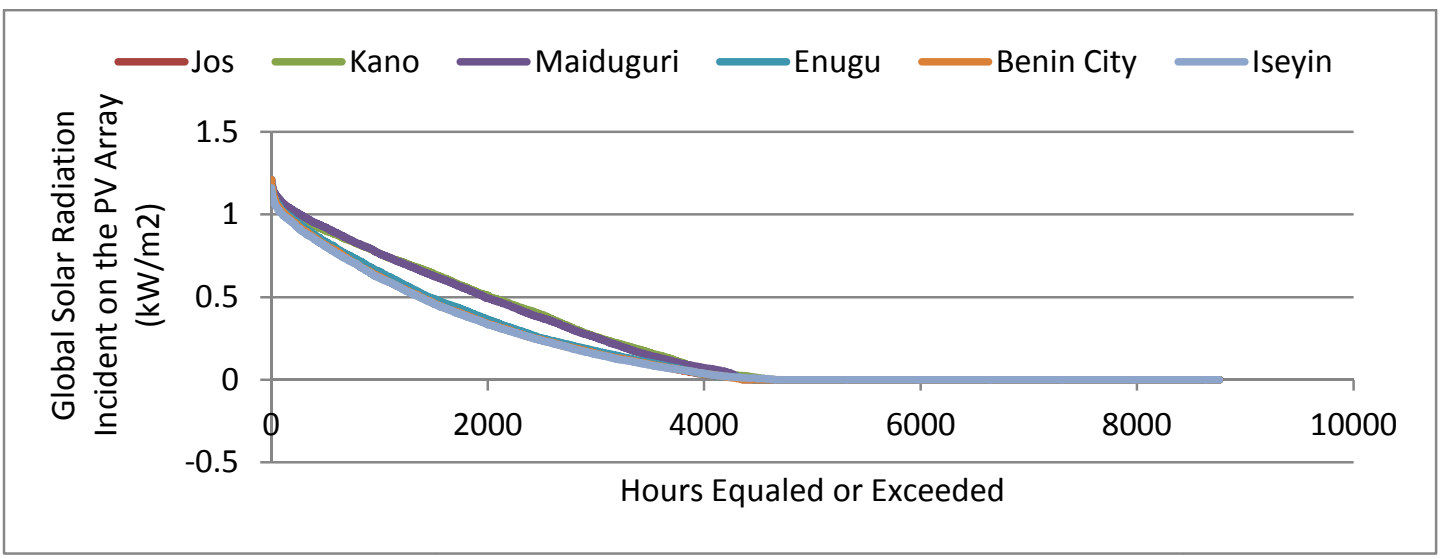

Fig. 5: Plot of 24 Years' Annual Average Hours Equaled or Exceeded for Nigeria

Fig. 6 correlates the annual average solar radiation and PV module size for the 6 sites studied. Upon analysis, it was found that a good correlation subsists between incident irradiation and PV size. This relationship was observed to be inverse in proportionality between the two quantities, with the PV requirement growing with decline in solar radiation intensity. This can be attributed to the prevailing weight of daily global solar radiation on the sizing of photovoltaic systems. Fig. 6 also reveals an average 24 years annual solar radiation that ranged between Iseyin (SW) - 4.45 $\left(\mathrm{kWh} / \mathrm{m}^{2}\right.$.day) and Maiduguri (NE) - 6.07 $\left(\mathrm{kWh} / \mathrm{m}^{2}\right.$.day) with a matching PV rating of $190 \mathrm{~kW}$ and $115 \mathrm{~kW}$ respectively. 


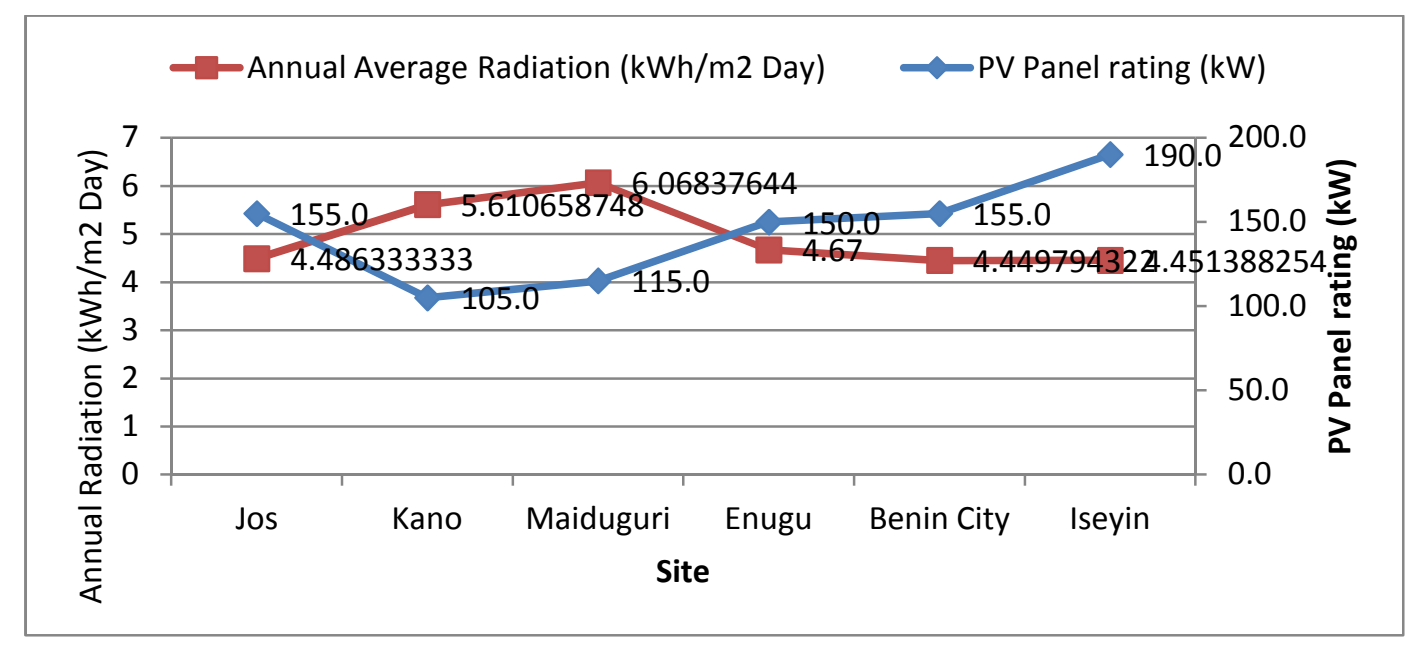

Fig 6: Correlation between the Monthly Average Solar Radiation and Solar Panel Size for Nigeria

From Table 9, considering the most cost effective PV standalone system design having a Loss of Load Probability (LOLP) of 0.01 (Hontoria et al, 2005; Shen, 2009; Khatib et al, 2013), produced an average excess electricity corresponding to $26.3 \%$ of annual generation. The reason for this excess however, is due to a reduction in daily hours of sunshine during the rainy season period, when average sunshine duration ranges between 3 and 4 hours in the north and 1 to 2 hours in the south. Consequently, a design that will cater for a load profile of 200 rural homes must necessarily include a realistic battery charging requirement to account for the days of limited solar radiation. Hence, the battery days of autonomy ranged between 48.7 hours for NW and 68.9 hours for SS at a $50 \%$ initial state of charge, which was chosen in order to extend battery life (Hund et al, 2010; Hund, 2009; Hunt, 2009; Overview of the NERC regulations, 2012; Multi-Year Tariff Order, 2011; Branker et al, 2011; Lorenz et al, 2008). However, this unequivocally gives rise to an excess in energy generated annually when the period of higher sunshine duration is balanced with those of lower duration over an entire year. This excess can easily be harnessed in the form of generation known as embedded generation, which is defined as a form of generation where excess renewable energy generated by a consumer above $1 \mathrm{MW}$ may be sold to a nearby distribution network (Overview of the NERC regulations, 2012; Multi-Year Tariff Order, 2011). This sales to the grid have the advantage of reducing the LCOE, as revealed by equation 13. It is also noteworthy that the excess may not be sold to the grid at all times, as it will be wasted when lower than $1 \mathrm{MW}$, if the optimum battery capacity by design could not take care of this excess. The battery specification employed in the study is presented in table 9. It reveals the optimized rated capacity (or nominal capacity) of the battery, which is the amount of energy that could be pulled out from it at a particular constant current, starting from a fully charged state. 
Table 9: Technical Requirements Employed for the PV Standalone System Design

\begin{tabular}{lllllll}
\hline Site & $\begin{array}{l}\text { PV } \\
\text { Panel } \\
\text { rating } \\
\text { (kW) }\end{array}$ & $\begin{array}{l}\text { PV hours of } \\
\text { Operation } \\
\text { (hrs/yr) }\end{array}$ & $\begin{array}{l}\text { Battery } \\
\text { Nominal } \\
\text { Capacity } \\
\text { (kWh) }\end{array}$ & $\begin{array}{l}\text { Battery Usable } \\
\text { Capacity (kWh) }\end{array}$ & $\begin{array}{l}\text { Battery } \\
\text { Autonom } \\
\text { y (hours) }\end{array}$ & $\begin{array}{l}\text { Excess } \\
\text { Electricity (\% } \\
\text { of Production) }\end{array}$ \\
\hline Jos (NC) & 155.0 & 4,472 & 1469 & 1,028 & 68.9 & 19.3 \\
Kano (NW) & 105.0 & 4,466 & $\$ 0.127$ & 1,037 & 48.7 & 17.9 \\
Maiduguri & & & 1,102 & 771 & 51.7 & 23.0 \\
(NE) & 115.0 & 4,357 & 1,274 & 892 & 59.8 & 28.6 \\
Enugu (SE) & 150.0 & 4,457 & 1,469 & 1,028 & 68.9 & 28.0 \\
Benin (SS) & 155.0 & 4,353 & 1382 & 968 & 64.9 & 41.1 \\
Iseyin (SW) & 190.0 & 4,313 & & & & \\
\hline
\end{tabular}

The life cycle cost (NPC), which captures all the cost all through the operational life $(25$ years) of the system is presented in Fig. 7. Firstly, a project life of 25 years was specified in the analysis due to the average life span of solar panels. However, including replacement cost for each component within the analysis, makes design setup project beyond the required twenty five years' module lifetime. Hence, this makes the design setup more affordable for higher operational life cycle periods, and since each component cost is expected to reduce over the years, the LCOE is projected to further decline. This study reveals that the influence of solar panel on the total NPC is approximately $52 \%$ for the Kano site, $73.4 \%$ for Maiduguri, $51 \%$ for Enugu, $54 \%$ for
Benin, $75 \%$ for Iseyin, and 53\% for Jos. The residual costs are then borne by the battery and converter's initial, maintenance and replacement costs. With the recent rate of decline in prices of solar panels (Branker et al, 2011; Lorenz et al, 2008; Renewable Power Generation Costs, 2012), their influence on life cycle cost is projected to progressively decline, thus making PV systems much more competitive with grid electricity. Fig. 7 presents a comparison between total NPC and initial capital cost, and it reveals a similar pattern for both costs. However, this similarity is due to the use of the same technology by all sites, though the initial costs are less than NPC for each site. 


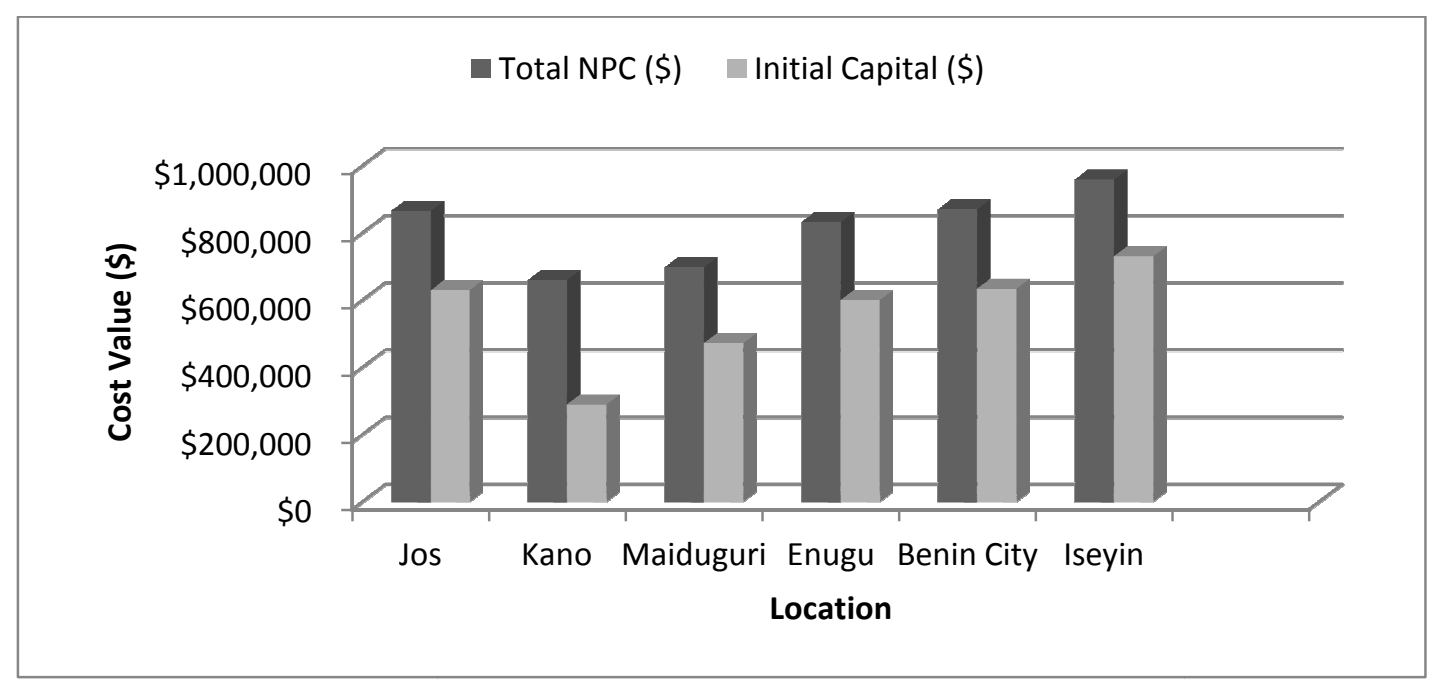

Fig 7: Comparison between Net Present Cost (NPC) and Initial Capital for PV Standalone System

An econometric ranking for all studied sites is presented in Table 10. The PV economics reveals that the $\mathrm{LCOE}$ is directly proportional to total NPC for all sites. More so, Fig. 8 shows the most excellent location in Nigeria by LCOE. It reveals that Iseyin is the poorest in terms of LCOE at $\$ 0.579 / \mathrm{kWh}$ and Kano is the finest with $\$ 0.398 / \mathrm{kWh}$.
Hence, the use of PV standalone systems equates to savings of $7.1 \%$ and $56 \%$ respectively on an equivalent DSS that will cover the same load for this communities, with the added advantage of savings in 279 tons of $\mathrm{CO}_{2}$ green house gas emissions (GHG).

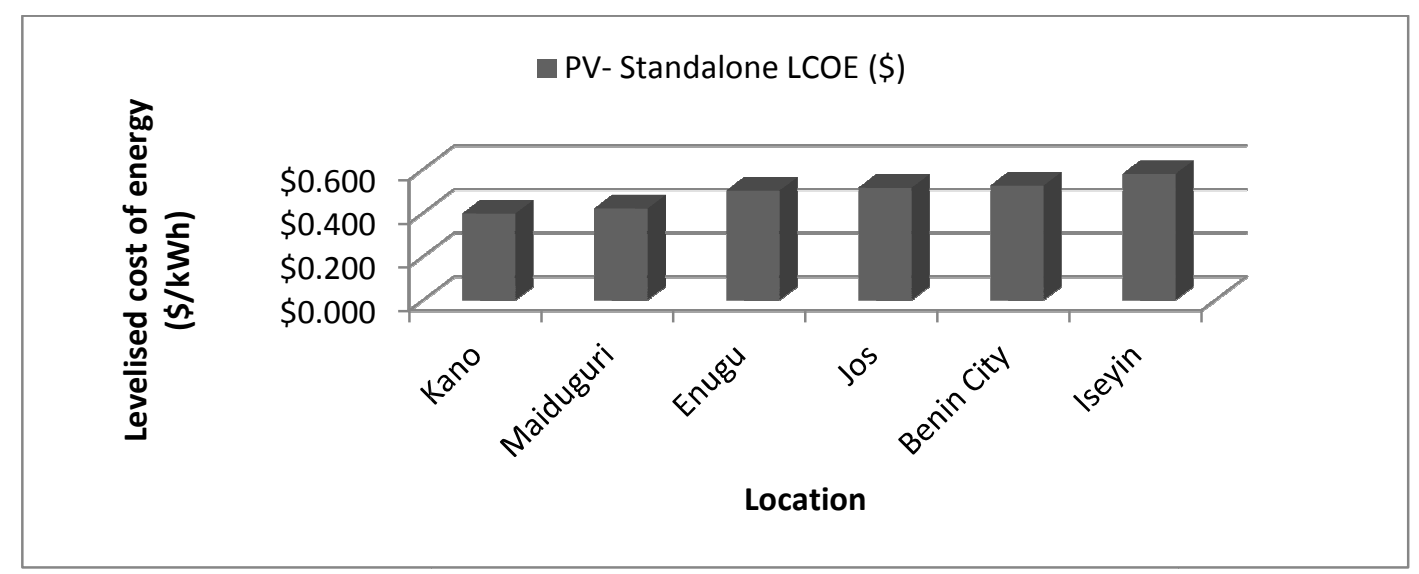

Fig 8: LCOE for PV Standalone System 
Table 10: Total NPC and LCOE Values for the PV Standalone System Design

\begin{tabular}{|c|c|c|}
\hline Site & $\begin{array}{l}\text { Total NPC } \\
(\$)\end{array}$ & LCOE (\$/kWh) \\
\hline Kano & $\$ 660,209$ & $\$ 0.398$ \\
\hline Maiduguri & $\$ 697,700$ & $\$ 0.421$ \\
\hline Enugu & $\$ 832,253$ & $\$ 0.503$ \\
\hline Jos & $\$ 865,771$ & $\$ 0.516$ \\
\hline Benin & $\$ 870,270$ & $\$ 0.526$ \\
\hline Iseyin & $\$ 958,655$ & $\$ 0.579$ \\
\hline
\end{tabular}

Prospect of Standalone Wind-To-Electricity Project in the Sites

The results of wind profile analysis at the site are as shown in Figs. 9 and 10. A few of the sites have missing wind speed values for 2 to 3 years (2008-2010). Fig. 9 shows the average monthly wind speed profiles for a period spanning between 1987 and 2010. The figure reveals that the 24 years monthly wind speed varied between $3.476(\mathrm{~m} / \mathrm{s})$ in November for Benin City (SS) and 10.062 $(\mathrm{m} / \mathrm{s})$ in December for Jos (NC). Fig. 10 reveals the average yearly wind speed profiles for the period covering 1987 and 2010. Jos (NC) is observed to have the highest yearly average wind speed - 11.783 $\mathrm{m} / \mathrm{s}$ in 1993, while Iseyin (SW) had the lowest - $1.842 \mathrm{~m} / \mathrm{s}$ in 1999. Moreover, the hours equaled or exceeded for a range of mean measured wind speeds across the period (Fig. 11) revealed that $67.2 \%$ of the data spread are values above $3.0 \mathrm{~m} / \mathrm{s}$ for the poorest site in terms of wind profile, and 91.9\% for the best wind profile in Jos. This discovery proves that majority of the sites are well-suited to contemporary wind turbines, since recent wind turbines for power generation have a cut-in speed of 3 $\mathrm{m} / \mathrm{s}$. Therefore, this reveals that wind power can be harnessed throughout the year with corresponding higher returns on investment.

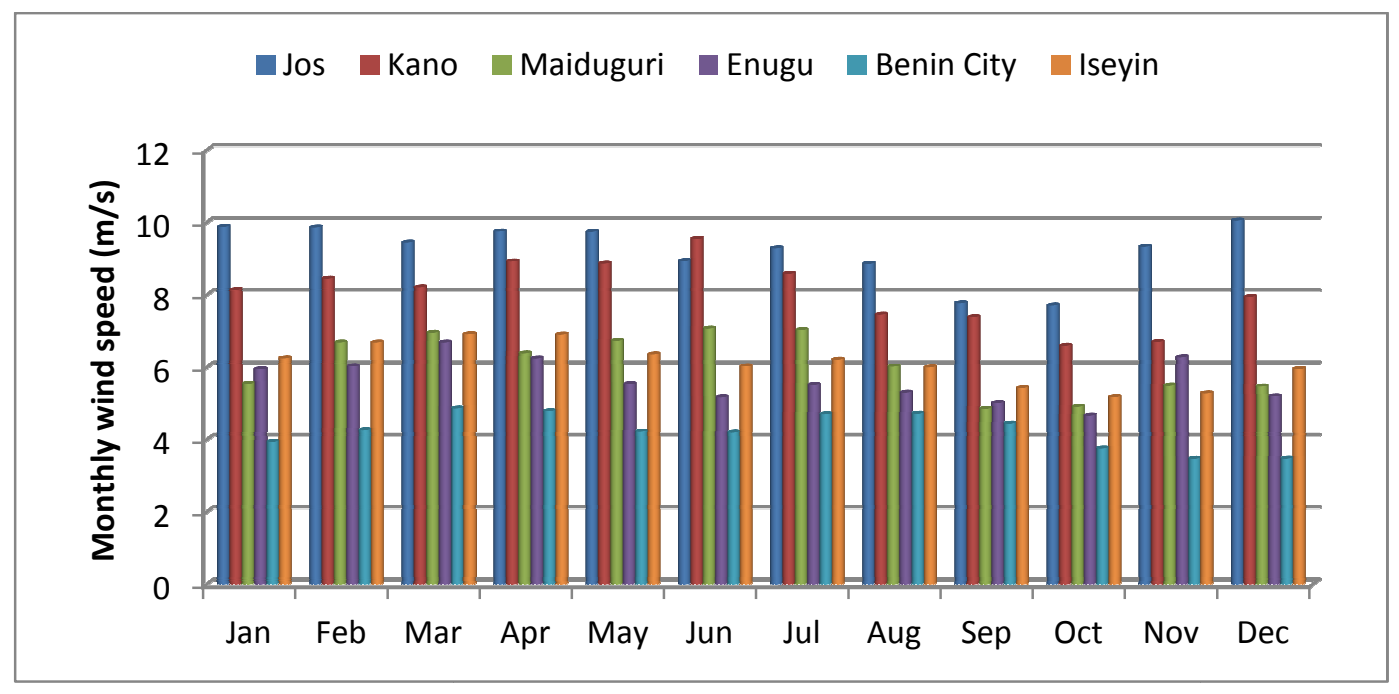

Fig. 9: Plot of 24 Years' Monthly Average Wind Speeds 


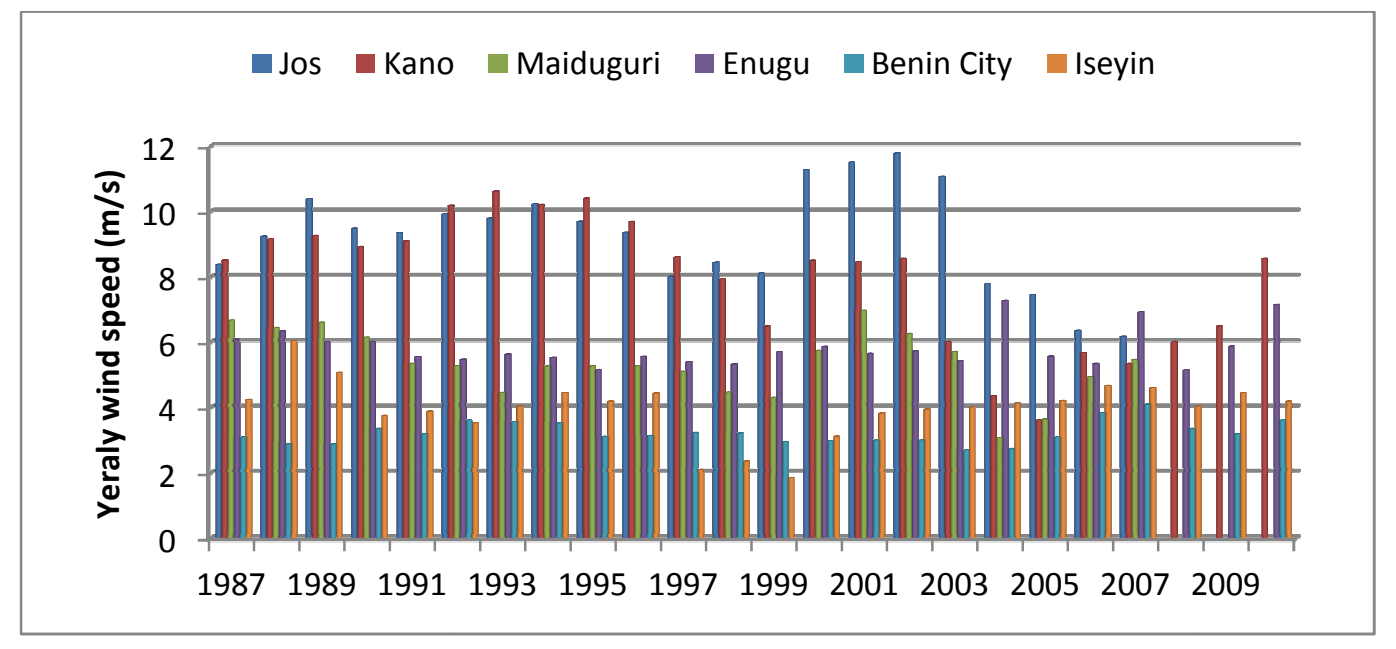

Fig. 10: Plot of 24 Years' Annual Average Wind Speeds

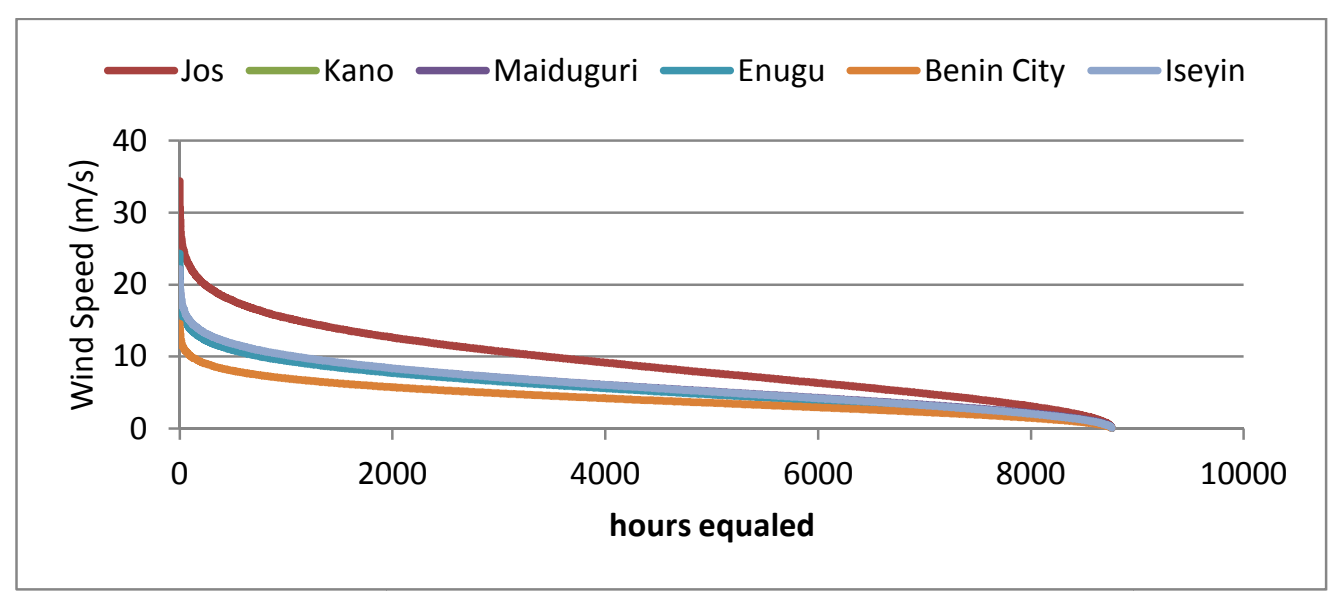

Fig. 11: Plot of 24 Years' Annual Average Hours Equaled or Exceeded for Different Wind Speeds

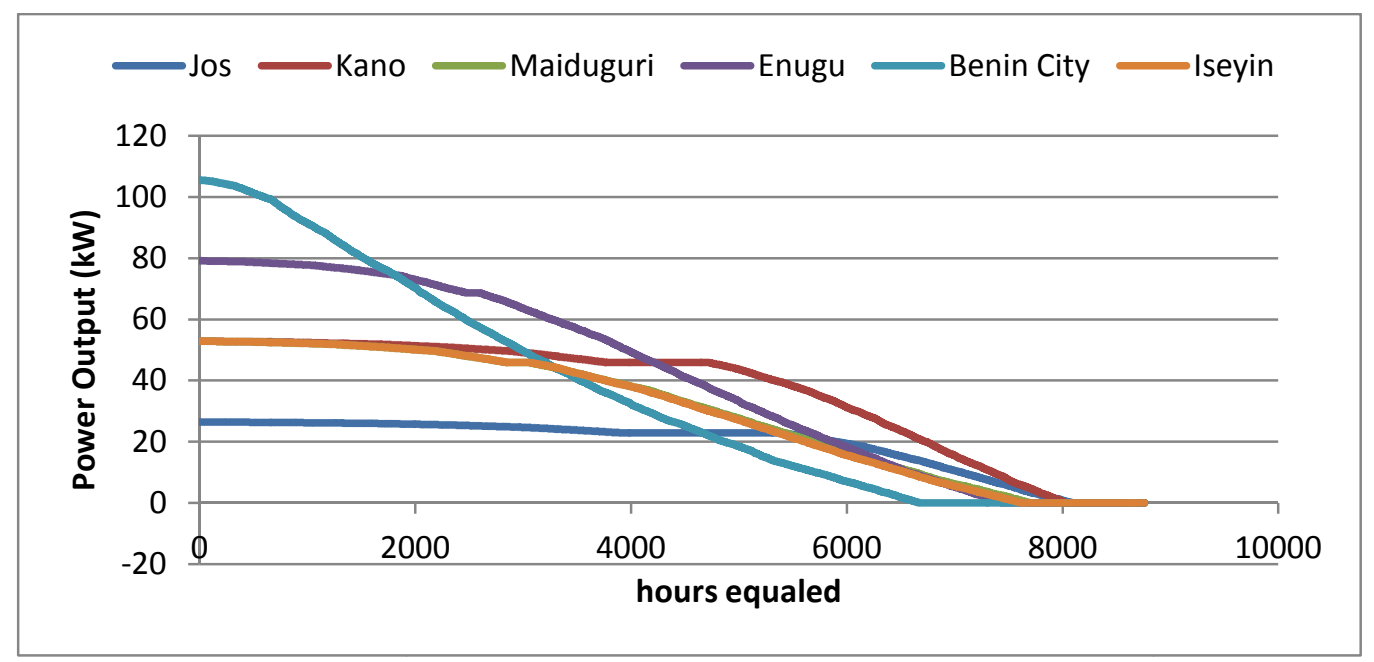

Fig. 12: Plot of 24 Years' Annual Average PGE 2025 Power Output Duration Curve (kW) 
The hours equaled for power generated for each site from their respective turbine sizing based on particular wind speed profiles is presented in Fig. 12. The SS requires the highest turbine size of $100 \mathrm{~kW}$, thereby generating more excess power than any other site, howbeit, for a very short period as it only generates power for equal or less than about $68 \%$ of the time. On the other hand, a site like Kano in the NW is sized at $50 \mathrm{~kW}$ because of a very favorable wind profile that makes this site consistently generate for $90 \%$ of the hourly duration in a year. As a result, Table 11 reveals that Benin city has the peak battery capacity requirement, which is to balance for approximately a third of the yearly hourly duration without turbine production.

Table 11: Technical Requirements and Correlation of Electricity Consumed as a Percentage of Wind Standalone Production

\begin{tabular}{lllllll}
\hline Site & $\begin{array}{l}\text { Wind } \\
\text { Turbine } \\
\text { rating }(\mathbf{k W})\end{array}$ & $\begin{array}{l}\text { Wind hours of } \\
\text { Operation } \\
(\mathbf{h r s} / \mathbf{y r})\end{array}$ & $\begin{array}{l}\text { Battery } \\
\text { Nominal } \\
\text { CapacityBattery Usable } \\
\mathbf{( k W h )} \text { Capacity (kWh) (hours) }\end{array}$ & $\begin{array}{l}\text { Battery } \\
\text { (kutonomy }\end{array}$ & $\begin{array}{l}\text { Excess } \\
\text { Electricity (\% } \\
\text { of Production) }\end{array}$ \\
\hline Jos & 50.0 & 8,089 & 302 & 212 & 14.2 & 59.0 \\
Kano & 50.0 & 8,025 & 367 & 257 & 17.2 & 56.6 \\
Enugu & 75.0 & 7,444 & 691 & 484 & 32.4 & 60.4 \\
Benin & 100.0 & 6,679 & 1,123 & 786 & 52.7 & 54.1 \\
Maiduguri & 50.0 & 7,701 & 583 & 408 & 27.4 & 45.9 \\
Iseyin & 50.0 & 7,619 & 821 & 575 & 38.5 & 45.3 \\
\hline
\end{tabular}

Table 11 reveals an average excess electricity equivalent to $54 \%$ of annual generation across all sites because wind power is generated on average, for about $80 \%$ of the time within the studied sites in Nigeria (see Fig. 11 \& Table 11). This gives rise to wind energy generation over twothirds of every hour of the day, thus, an average optimal battery size of 30.8 hours of autonomy suitably matches the load requirement. Also, it is revealed that for an average of about $24 \%$ of the annual hourly duration, the turbines can produce at the rated capacity since the rated speed for the PGE 20/25 turbines used in the design is 9 $\mathrm{m} / \mathrm{s}$ (Fig. 11). This will certainly encourage good returns on investment and an opportunity for embedded generation (Overview of the NERC regulations, 2012; Multi-Year Tariff Order, 2011). From table 12 , it is observed that Wind Standalone System (WSS) is in general, more cost efficient due to an average savings of $80 \%$ on battery requirement in comparison to $\mathrm{PV}$ Standalone System (PSS).

Table 12: Econometrics Analysis for Wind Standalone System

\begin{tabular}{lllllll}
\hline Site & $\begin{array}{l}\text { Total NPC } \\
(\$)\end{array}$ & Total NPC & $\begin{array}{l}\text { Initial } \\
\text { Capital (\$) }\end{array}$ & Initial Capital & $\begin{array}{l}\text { LCOE } \\
\text { (\$) }\end{array}$ & LCOE \\
\hline Jos & $\$ 214,644$ & $33,269,820$ & $\$ 130,740$ & $20,264,700$ & 0.129 & NGN 20.00 \\
Kano & $\$ 238,263$ & NGN 36,930,765 & $\$ 141,720$ & NGN 21,966,600 & 0.144 & NGN 22.32 \\
Maiduguri & $\$ 279,356$ & NGN 43,300,180 & $\$ 158,820$ & NGN 24,617,100 & 0.168 & NGN 26.04 \\
Iseyin & $\$ 358,700$ & NGN 55,598,500 & $\$ 192,080$ & NGN 29,772,400 & 0.217 & NGN 33.64 \\
Enugu & $\$ 385,754$ & NGN 59,791,870 & $\$ 222,870$ & NGN 34,544,850 & 0.233 & NGN 36.12 \\
Benin & $\$ 541,558$ & NGN 83,941,490 & $\$ 310,820$ & NGN 48,177,100 & 0.327 & NGN 50.69 \\
\hline
\end{tabular}


Table 12 shows the NPC of utilizing only WSS for power generation in each community, which reveals differential in NPC for all sites as a result of all sites having different wind speed profiles. This is because the wind energy resource is very close to the turbines' rated speed at some locations, while others are a bit far off. Thus, those close in value to the turbines' rated speed produced at the turbines' rated speed for up to $47 \%$ of the time in Jos, which has the best wind speed profile. Hence, this site required a lower capacity rated turbine of $50 \mathrm{~kW}$ in comparison to a site such as Benin city which required $100 \mathrm{~kW}$ to meet its load demand. After the analysis, the total NPC averaged $142 \%$ less for the WSS than that for the PSS when all sites were considered and the greatest differential of NPC by cost type was associated with capital cost.

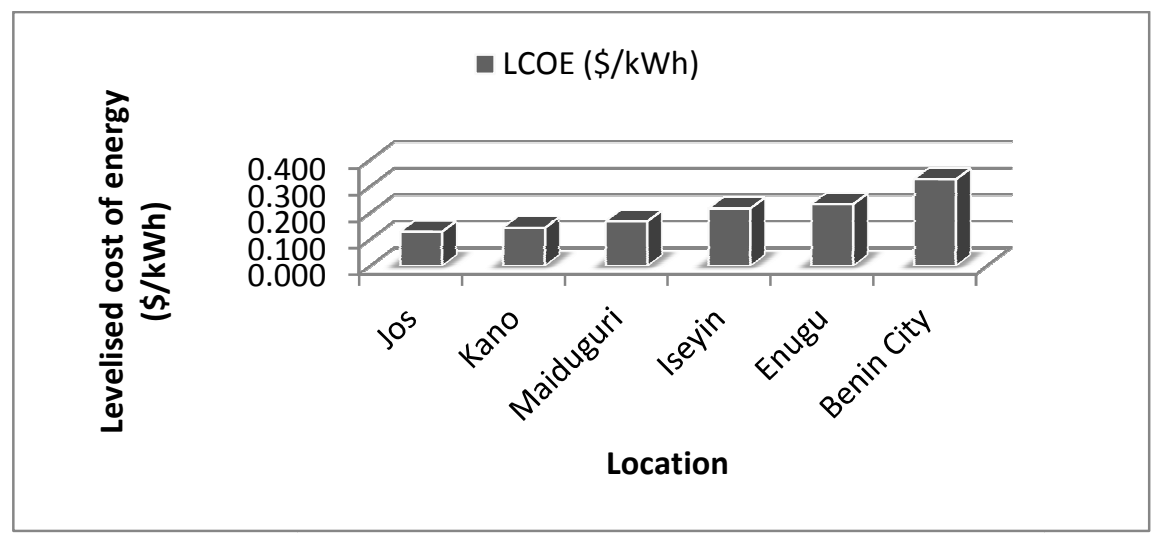

Fig 13: Net Present Cost (NPC) Summary - Comparison between Wind Standalone Systems

Comparing the total NPC and LCOE for all sites as presented in table 12 reveals that the LCOE correlates for all sites with the NPC values. Hence, Fig. 13 comparatively ranks these sites by LCOE, with Benin city being the poorest at $\$ 0.327 / \mathrm{kWh}$ and Jos the best with $\$ 0.129 / \mathrm{kWh}$. This values equates to $89.6 \%$ and $380 \%$ savings respectively on a comparable DSS applied to meet the same load requirement for these communities. This comes with an added advantage of an additional savings in 279 tons of $\mathrm{CO}_{2}$ greenhouse gas (GHG) emissions which is equivalent to planting 25 hectares of forest for $\mathrm{CO}_{2}$ absorption.
Evaluation of the Potential of Solar-Wind
Hybrid System The logical advantage of hybridizing renewable energy resources over each respective $\mathrm{RE}$ system is in the fact that the base load will be covered by the most copious and firmly available energy source, thereby sinking the technical requirements and the cost of the storage batteries. The economic costs of employing wind and PV systems, as standalone or in hybrid format are presented in Tables 13-15 and Fig. 14.

\section{Table 13: Results of Econometrics Analysis for the Deployment of Solar-Wind Hybrid Technology (Ranking By Total NPC)}

\begin{tabular}{lllllll}
\hline Site & $\begin{array}{l}\text { Total } \\
\text { NPC }(\$)\end{array}$ & $\begin{array}{l}\text { Total NPC } \\
\text { (NGN) }\end{array}$ & $\begin{array}{l}\text { Initial } \\
\text { Capital } \\
\text { (\$) }\end{array}$ & Initial Capital & $\begin{array}{l}\text { LCOE } \\
\text { (\$) }\end{array}$ & LCOE \\
\hline Kano & $\$ 253,550$ & NGN 39,300,250 & $\$ 157,460$ & NGN 24,406,300 & 0.153 & NGN 23.72 \\
Jos & $\$ 286,688$ & NGN 44,436,640 & $\$ 168,700$ & NGN 26,148,500 & 0.172 & NGN 26.66 \\
Maiduguri & $\$ 421,231$ & NGN 65,290,805 & $\$ 252,580$ & NGN 39,149,900 & 0.252 & NGN 39.06 \\
Iseyin & $\$ 492,543$ & NGN 76,344,165 & $\$ 335,940$ & NGN 52,070,700 & 0.295 & NGN 45.73 \\
Enugu & $\$ 507,056$ & NGN 78,593,680 & $\$ 324,860$ & NGN 50,353,300 & 0.304 & NGN 47.12 \\
Benin & $\$ 594,877$ & NGN 92,205,935 & $\$ 391,020$ & NGN 60,608,100 & 0.356 & NGN 55.18 \\
\hline
\end{tabular}


As revealed in tables 13 and 15 , the total NPC and LCOE for solar-wind hybrid in the selected sites did not produce any considerable improvement in terms of LCOE for the hybrid system over the WSS, although it is advantageous over the PSS for all sites. Thence, the WSS proves to be the best RE generation system for all the sites, which can adequately cater for the energy needs of the rural poor. Table 14 reveals the optimum combination of hybrid systems for this study.

Table 14: Technical Requirements and Electricity Consumed As a Percentage of Wind-PV Hybrid Production

\begin{tabular}{lllllll}
\hline & $\begin{array}{l}\text { Wind } \\
\text { Turbine } \\
\text { rating } \\
\text { (kW) }\end{array}$ & $\begin{array}{l}\text { PV } \\
\text { Panel } \\
\text { rating } \\
\text { (kW) }\end{array}$ & $\begin{array}{l}\text { Battery } \\
\text { Nominal } \\
\text { Capacity } \\
\text { (kWh) }\end{array}$ & $\begin{array}{l}\text { Battery } \\
\text { Autonomy } \\
\text { (hours) }\end{array}$ & $\begin{array}{l}\text { Excess } \\
\text { Electricity } \\
\text { (\%) } \\
\text { Production) }\end{array}$ & $\begin{array}{l}\text { Optimum } \\
\text { Ratio \% } \\
\text { (WIND:PV) }\end{array}$ \\
\hline Jos & 50.0 & 5 & 432 & 20.3 & 59.6 & $98 \%-2 \%$ \\
Kano & 50.0 & 5 & 400 & 18.8 & 57.4 & $97 \%-3 \%$ \\
Maiduguri & 50.0 & 10 & 821 & 38.5 & 49.3 & $94 \%-6 \%$ \\
Enugu & 50.0 & 40 & 994 & 46.6 & 51.7 & $82 \%-18 \%$ \\
Benin City & 75.0 & 45 & 1,015 & 47.6 & 51.5 & $81 \%-19 \%$ \\
Iseyin & 50.0 & 50 & 734 & 34.5 & 56.9 & $81 \%-19 \%$ \\
\hline
\end{tabular}

Table 15: LCOE for Different Energy Systems in Nigeria (Ranked By Hybrid System)

\begin{tabular}{|c|c|c|c|c|c|c|}
\hline Site & $\begin{array}{l}\text { PV LCOE } \\
\text { (\$/kWh) }\end{array}$ & $\begin{array}{l}\text { PV LCOE } \\
\text { (NGN/kWh) }\end{array}$ & $\begin{array}{l}\text { WIND } \\
\text { LCOE } \\
\text { (\$/kWh) }\end{array}$ & $\begin{array}{l}\text { WIND LCOE } \\
\text { (NGN/kWh) }\end{array}$ & $\begin{array}{l}\text { HYBRID LCOE } \\
\text { (\$/kWh) }\end{array}$ & $\begin{array}{l}\text { HYBRID LCOE } \\
\text { (NGN/kWh) }\end{array}$ \\
\hline Maiduguri & $\$ 0.398$ & NGN 61.69 & 0.144 & NGN 22.32 & 0.153 & NGN 23.72 \\
\hline Jos & $\$ 0.516$ & NGN 79.98 & 0.129 & NGN 20.00 & 0.172 & NGN 26.66 \\
\hline Kano & $\$ 0.421$ & NGN 65.26 & 0.168 & NGN 26.04 & 0.252 & NGN 39.06 \\
\hline Iseyin & $\$ 0.579$ & NGN 89.75 & 0.217 & NGN 33.64 & 0.295 & NGN 45.73 \\
\hline Enugu & $\$ 0.503$ & NGN 77.97 & 0.233 & NGN 36.12 & 0.304 & NGN 47.12 \\
\hline Benin & $\$ 0.526$ & NGN 81.53 & 0.327 & NGN 50.69 & 0.356 & NGN 55.18 \\
\hline
\end{tabular}




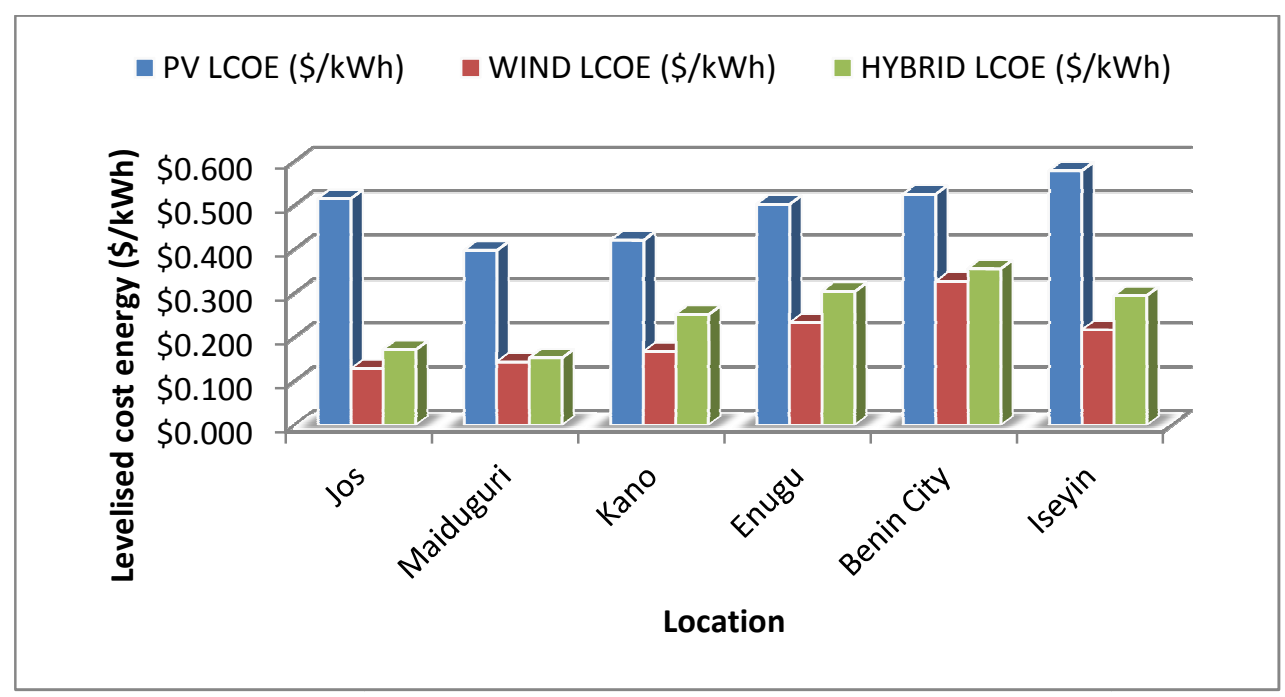

Fig 14: Net Present Cost (NPC) Summary - Comparison between Wind, PV and Hybrid Systems

Fig. 14 makes a comparison by LCOE for the WSS, PSS and hybrid energy system for all selected sites. Benin city was found to be the least viable site at $\$ 0.356 / \mathrm{kWh}$ and Kano, the most excellent with $\$ 0.153 / \mathrm{kWh}$. This result equate to $74 \%$ and $305 \%$ savings respectively on a comparable DSS designed to meet the same load demand for this communities.

In addition, Table 15 reveals that the solar resource, though very much viable for all selected sites falls beneath the potential of wind energy. Nonetheless, all renewable technologies performed better than the conventional DSS without batteries for all sites. The percentage improvement ranged between $74 \%$ to $380 \%$ by LCOE.

In conclusion, for the analysis covering standalone community based designs, the most excellent renewable technology that fulfills all the technical requirements, in addition to being the most economically viable substitute for power generation at the rural community of 200 homes in Jos
(NC), Maiduguri (NE), Kano (NW), Iseyin (SW), Enugu (SE), and Benin City (SS) is the wind standalone system. Also, with the government of Nigeria's present reform of electric tariff regime with grid electricity prices rising (Owonubi et al, 2009; Overview of the NERC regulations, 2012), and also based on the fact that research is ongoing to lower the price of wind turbine materials and solar panels, the competitiveness of RE generation will be on the increase.

\section{Econometrics of Distributed Generation}

The Federal government has made available the very much needed favorable environment that encourages growth in renewable energy (RE) generation by producers and consumers alike (Ajayi, 2010) through distributed generation. Table 16 presents the results of econometrics analysis when RE resources of all six sites are utilized as standalone systems in the form of distributed (embedded) generation. 
Table 16: LCOE and Grid Sales on Distributed Generation for a 10-Year Project Life Span with the Present MYTO for Nigeria

\begin{tabular}{|c|c|c|c|c|c|c|c|c|}
\hline State & $\begin{array}{c}\text { Optimum } \\
\text { LCOE } \\
\text { (WSS) } \\
\text { (\$/kWh) }\end{array}$ & $\begin{array}{l}\text { Optimal } \\
\text { WSS } \\
\text { capacity } \\
\text { (MW) }\end{array}$ & $\begin{array}{l}\text { Grid sales } \\
\text { at optimal } \\
\text { turbine } \\
\text { size } \\
(\mathrm{kWh} / \mathrm{yr})\end{array}$ & Remark & $\begin{array}{c}\text { Optimum } \\
\text { LCOE } \\
\text { (PSS) } \\
\text { (\$/kWh) }\end{array}$ & $\begin{array}{l}\text { Optimal } \\
\text { PSS } \\
\text { capacity } \\
\text { (MW) }\end{array}$ & $\begin{array}{c}\text { Grid sales } \\
\text { at optimal } \\
\text { PV array } \\
\text { size } \\
(\mathrm{kWh} / \mathrm{yr})\end{array}$ & Remark \\
\hline Kano & -0.132 & 18 & $96,403,320$ & Excellent & -0.137 & 25 & $40,084,124$ & Excellent \\
\hline Maiduguri & -0.122 & 18 & $73,309,360$ & Excellent & -0.158 & 25 & $42,798,944$ & Excellent \\
\hline Jos & -0.136 & 18 & $103,477,904$ & Excellent & -0.082 & 25 & $34,397,072$ & Good \\
\hline Iseyin & -0.119 & 15 & $61,392,680$ & Excellent & -0.021 & 25 & $29,431,030$ & Fair \\
\hline Enugu & -0.116 & 18 & $65,136,536$ & Excellent & -0.059 & 25 & $32,462,230$ & Good \\
\hline Benin City & -0.070 & 15 & $31,311,816$ & Fair & -0.049 & 25 & $31,690,810$ & Fair \\
\hline
\end{tabular}

The design adopted in Table 16 and Figs. 15 to 25 , was such that all the sites utilized mono-crystalline solar panel ranging between $5 \mathrm{MW}$ and $45 \mathrm{MW}$ having the same specification as that in Table 7 , while for the wind energy generation, the sites used different rated wind turbines in multiples of $3 \mathrm{MW}$, with Iseyin and Benin city yielding their optimum return on investment at a rated capacity of $15 \mathrm{MW}$, while the others produced optimal results when cumulative wind turbines of $18 \mathrm{MW}$ were employed. Noteworthy is the fact that, although Jos optimally utilizes $18 \mathrm{MW}$, same with Kano, Maiduguri and Enugu, it leads in terms of return on investments as a result of higher grid sales which is directly proportional to Jos being the city having the most favorable wind speed amongst all sites. It is important to note that, in order to meet up with the renewable national policy, an excess electricity of $\geq 1$ MW monthly average is required to activate sale to a distribution network. The analysis carried out using the present policy on renewable energy distributed generation spanned a ten year project lifespan in line with the National Electricity Regulatory Commission's (NERC) 5-year plans (Multi-Year Tariff Order, 2011). As can be observed from Table 16 both technologies (PSS and WSS) yielded negative LCOE's, which equates to profits per year for all the sites. This further shows the immense potentials and opportunities in the renewable energy sector in Nigeria.

Tables 17 and 18 presents the current reform of electric tariff regime ongoing in Nigeria by government in terms of growth rates of forecasted electricity prices for 2012-2017 (Multi-Year Tariff Order, 2011).

Table 17: Wholesale Feed-in-Tariff for Land Mounted Wind Power Plant

\begin{tabular}{lrrrrr}
\hline YEAR & 2012 & 2013 & 2014 & 2015 & 2016 \\
\hline $\begin{array}{l}\text { Wholesale contract } \\
\text { prices (NGN/MWh) }\end{array}$ & & & & & \\
\hline
\end{tabular}

Table 18: Wholesale Feed-in-Tariff for Solar Power Plant

\begin{tabular}{lrrrrr}
\hline YEAR & 2012 & 2013 & 2014 & 2015 & 2016 \\
\hline $\begin{array}{l}\text { Wholesale } \\
\begin{array}{l}\text { contract prices } \\
\text { (NGN/MWh) }\end{array}\end{array}$ & & & & & \\
\hline
\end{tabular}




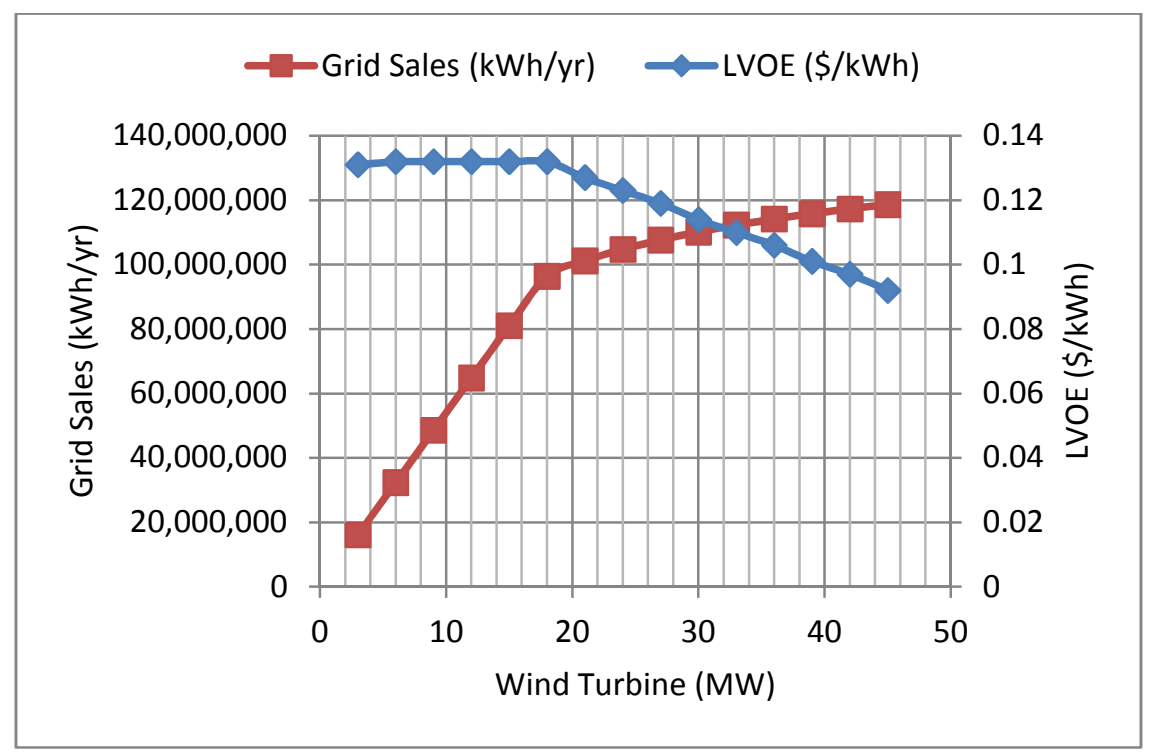

Fig 15: Techno-Economic Analysis Showing Grid Sales and LVOE for WSS Distributed Generation for Kano

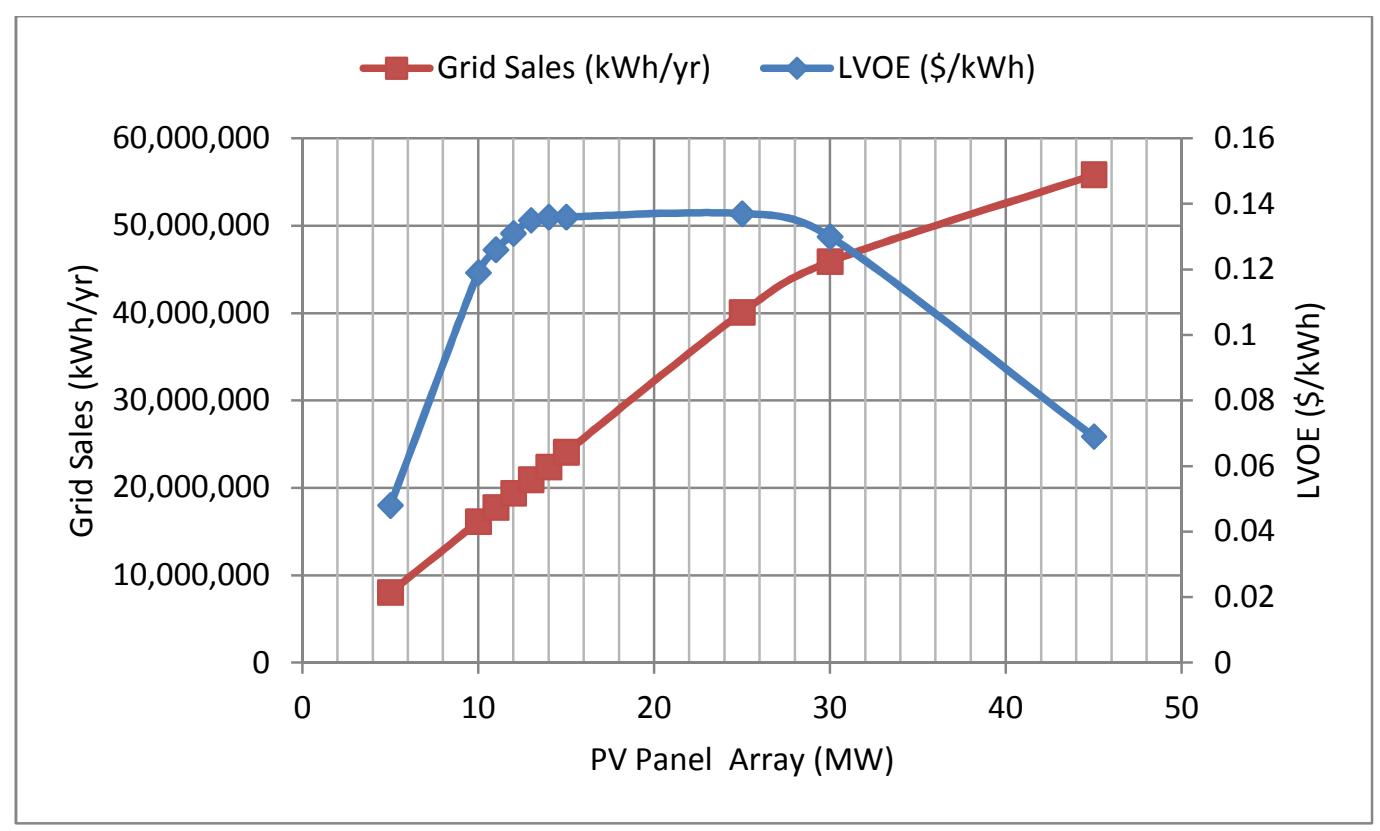

Fig 16: Techno-Economic Analysis Showing Grid Sales and LVOE for PSS Distributed Generation for Kano 


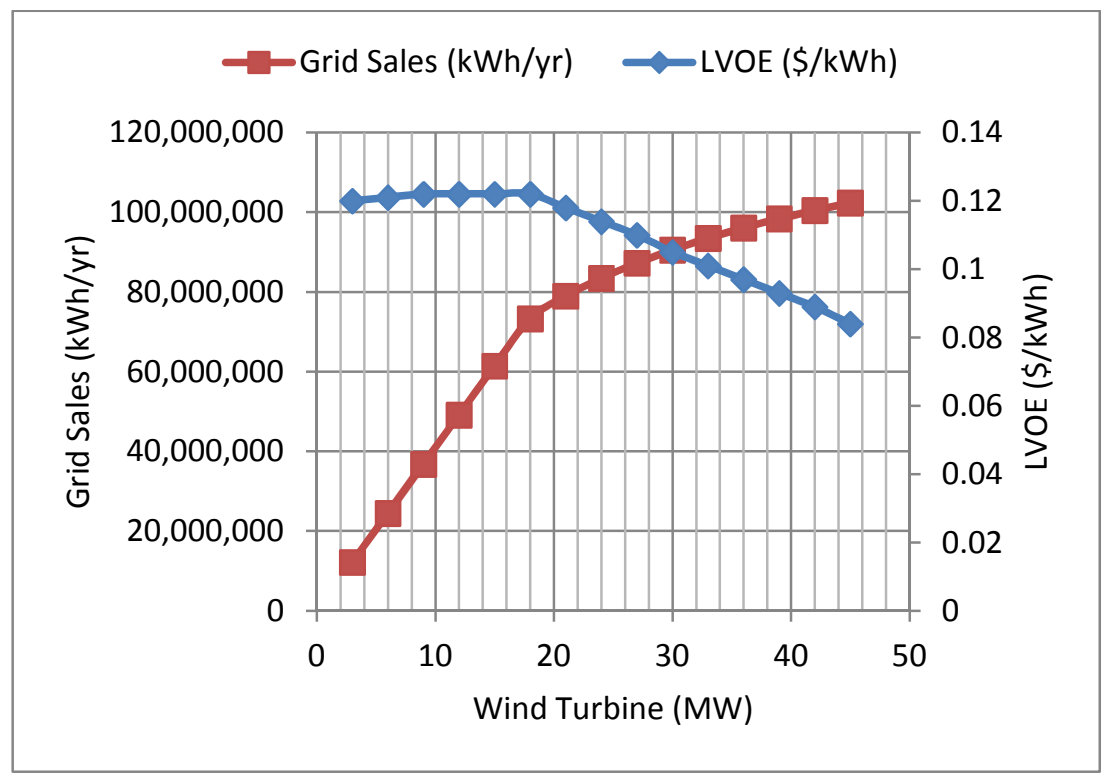

Fig 17: Techno-Economic Analysis Showing Grid Sales and LVOE for WSS Distributed Generation for Maiduguri

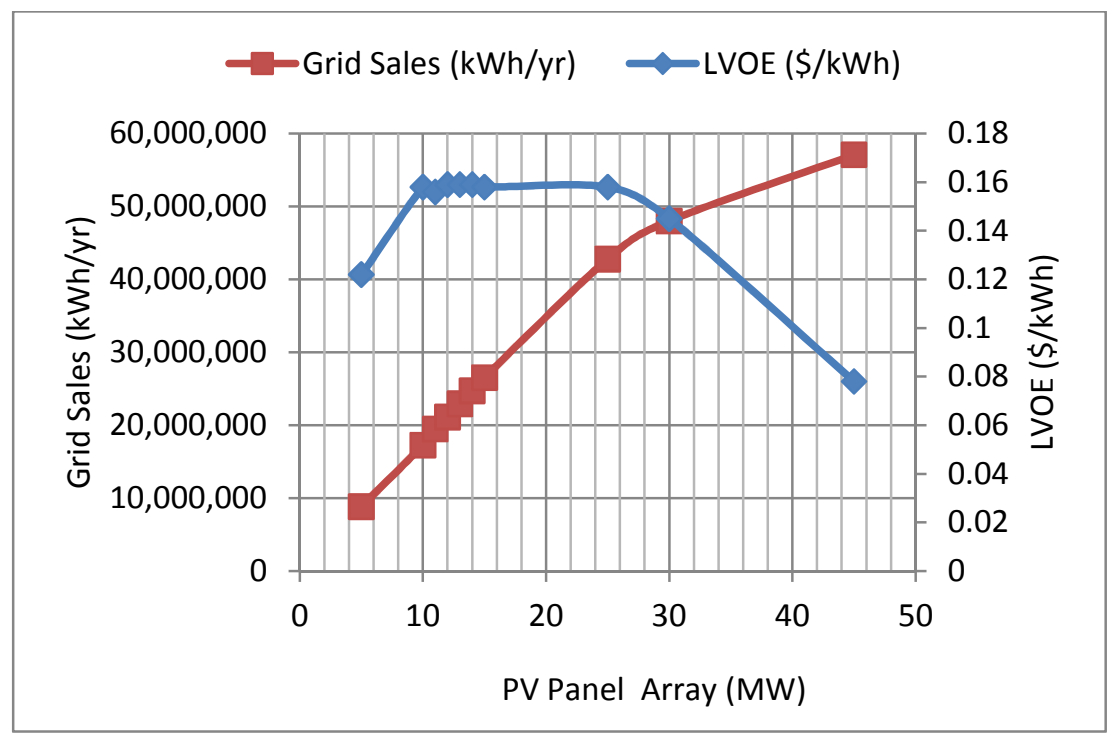

Fig 18: Techno-Economic Analysis Showing Grid Sales and LVOE for PSS Distributed Generation for Maiduguri 


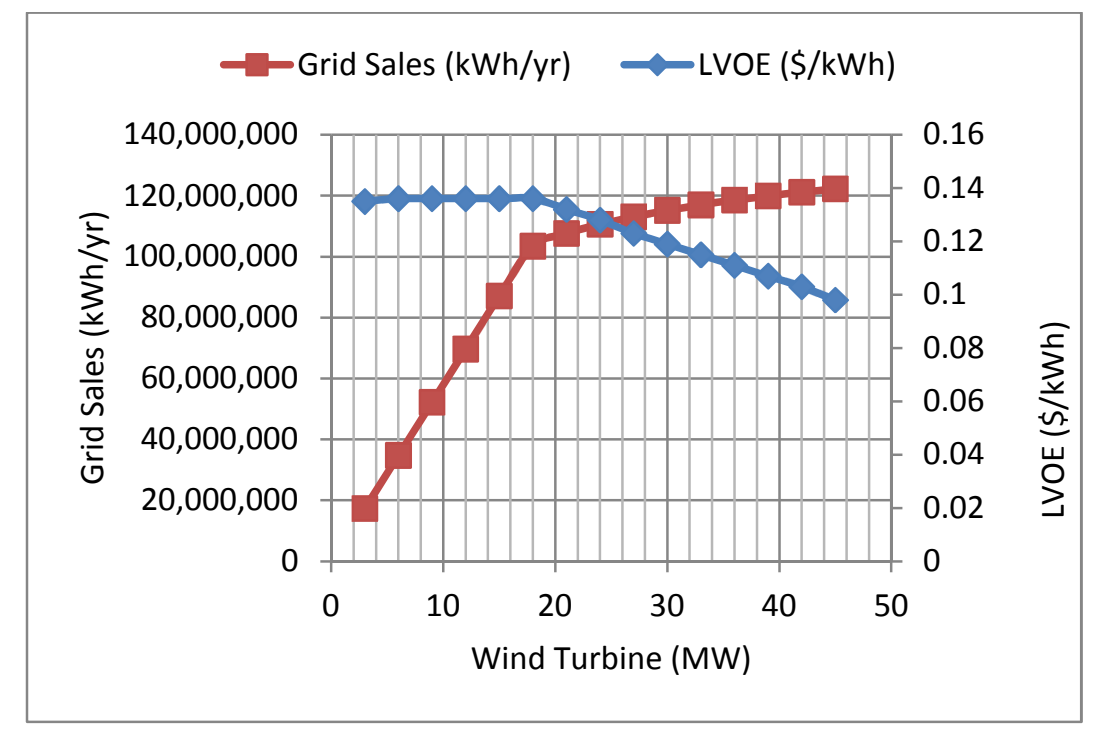

Fig 19: Techno-Economic Analysis Showing Grid Sales and LVOE for WSS Distributed Generation for Jos

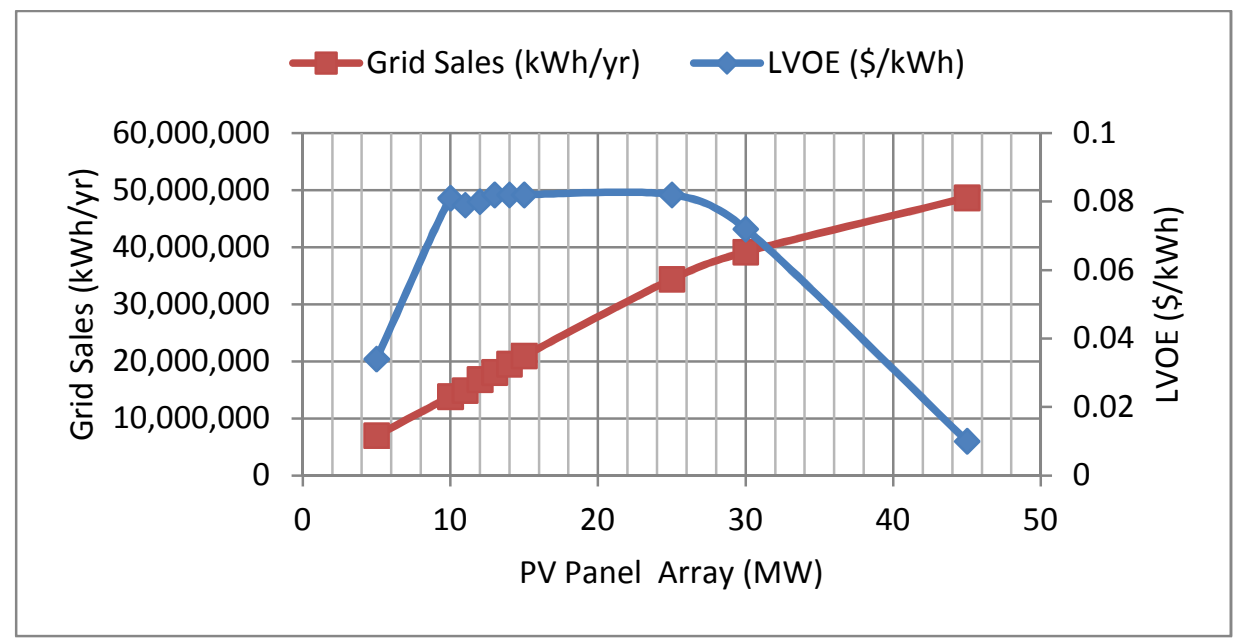

Fig 20: Techno-Economic Analysis Showing Grid Sales and LVOE for PSS Distributed Generation for Jos 


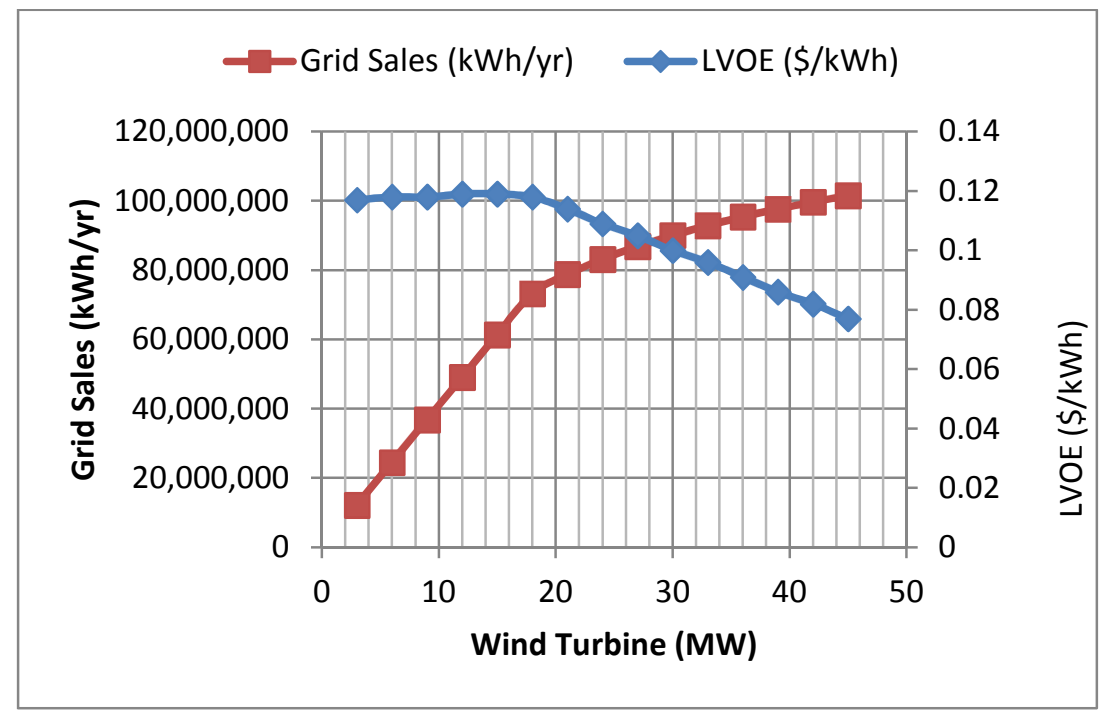

Fig 21: Techno-Economic Analysis Showing Grid Sales and LVOE for WSS Distributed Generation for Iseyin

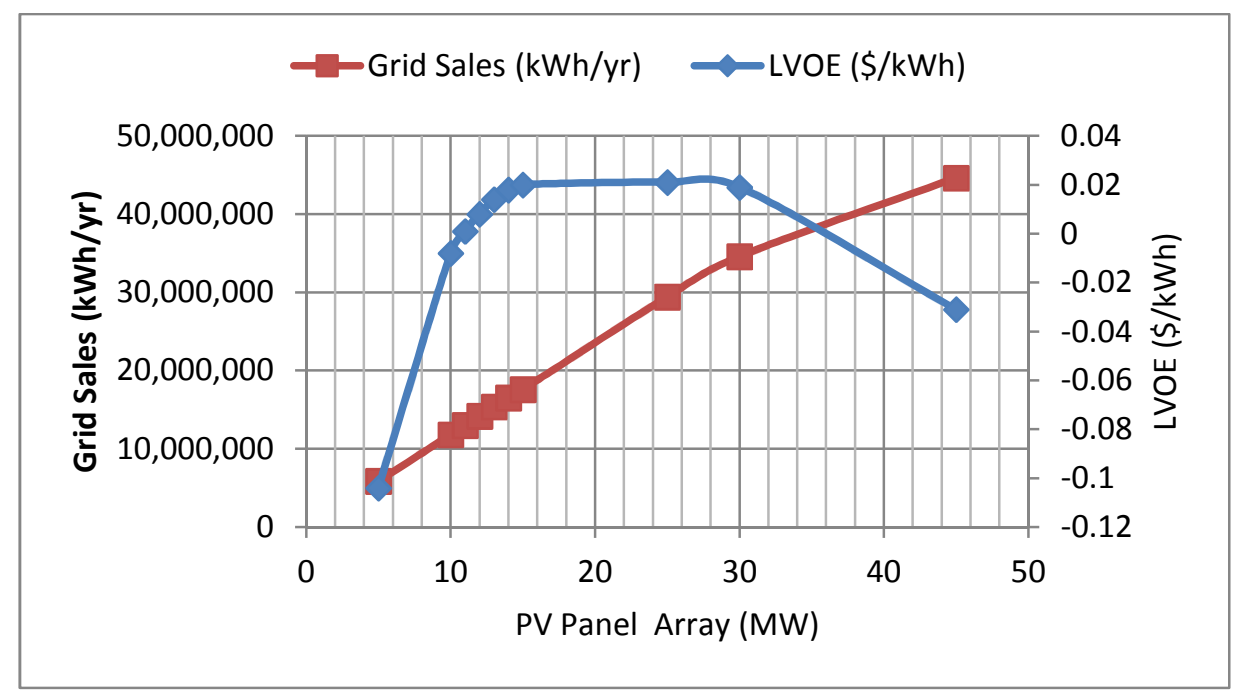

Fig 22: Techno-Economic Analysis Showing Grid Sales and LVOE for PSS Distributed Generation for Iseyin 


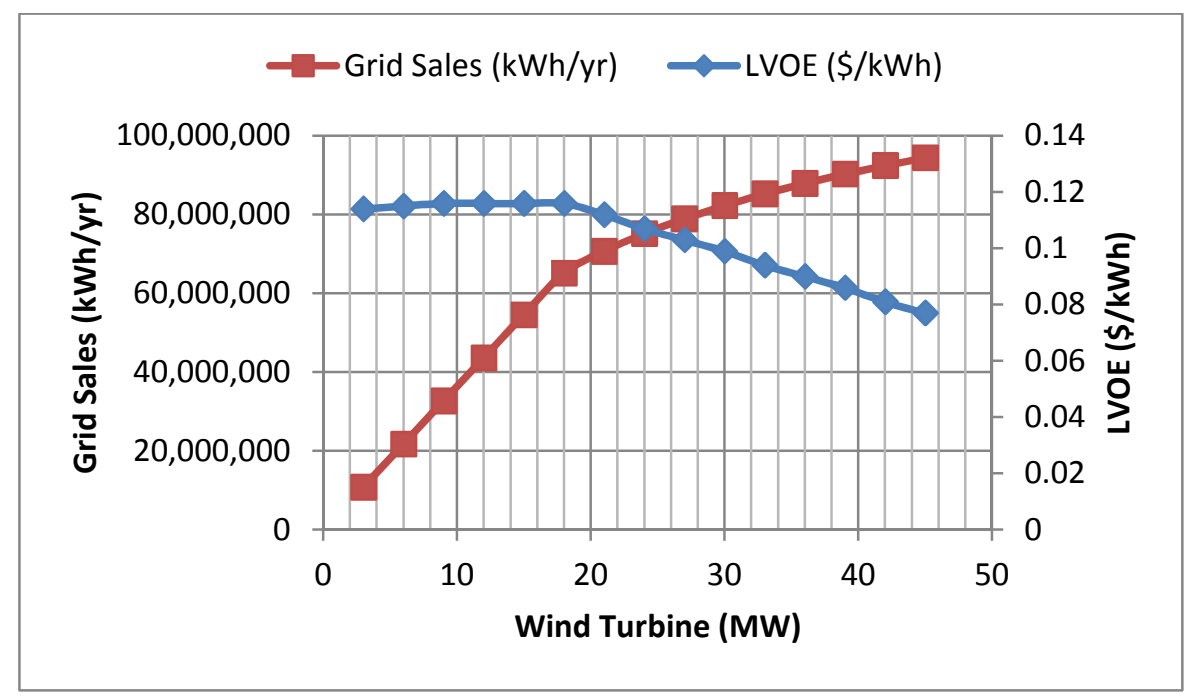

Fig 23: Techno-Economic Analysis Showing Grid Sales and LVOE for WSS Distributed Generation for Enugu

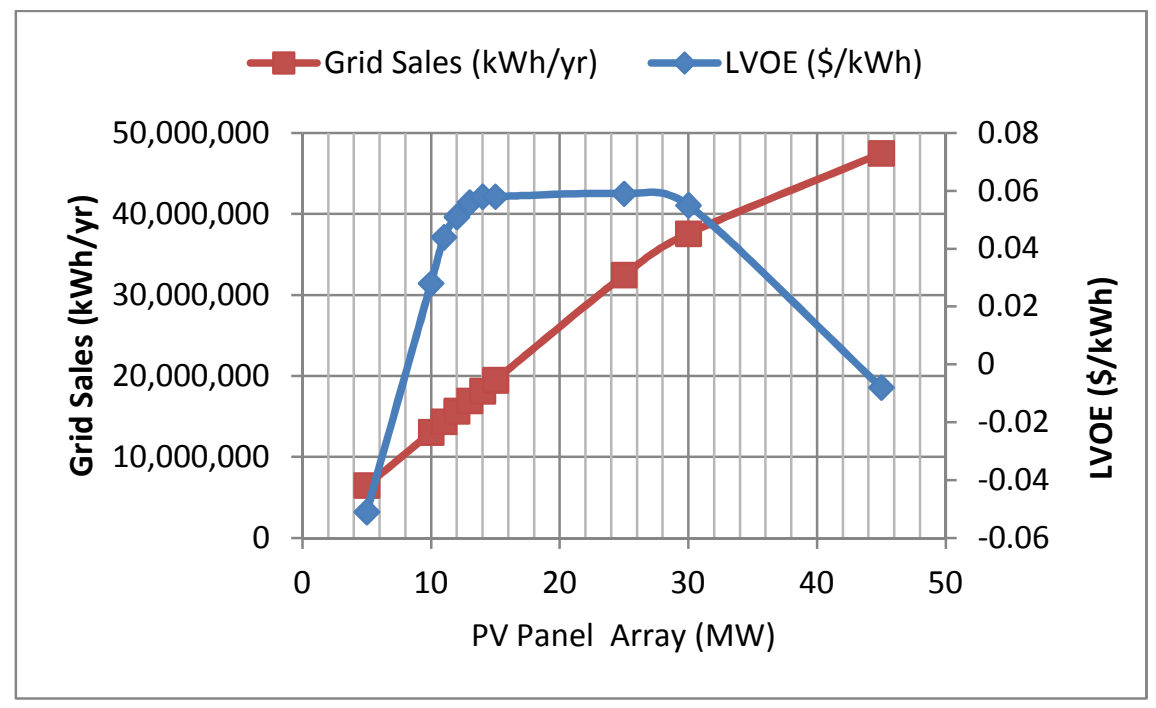

Fig 24: Techno-Economic Analysis Showing Grid Sales and LVOE for PSS Distributed Generation for Enugu 


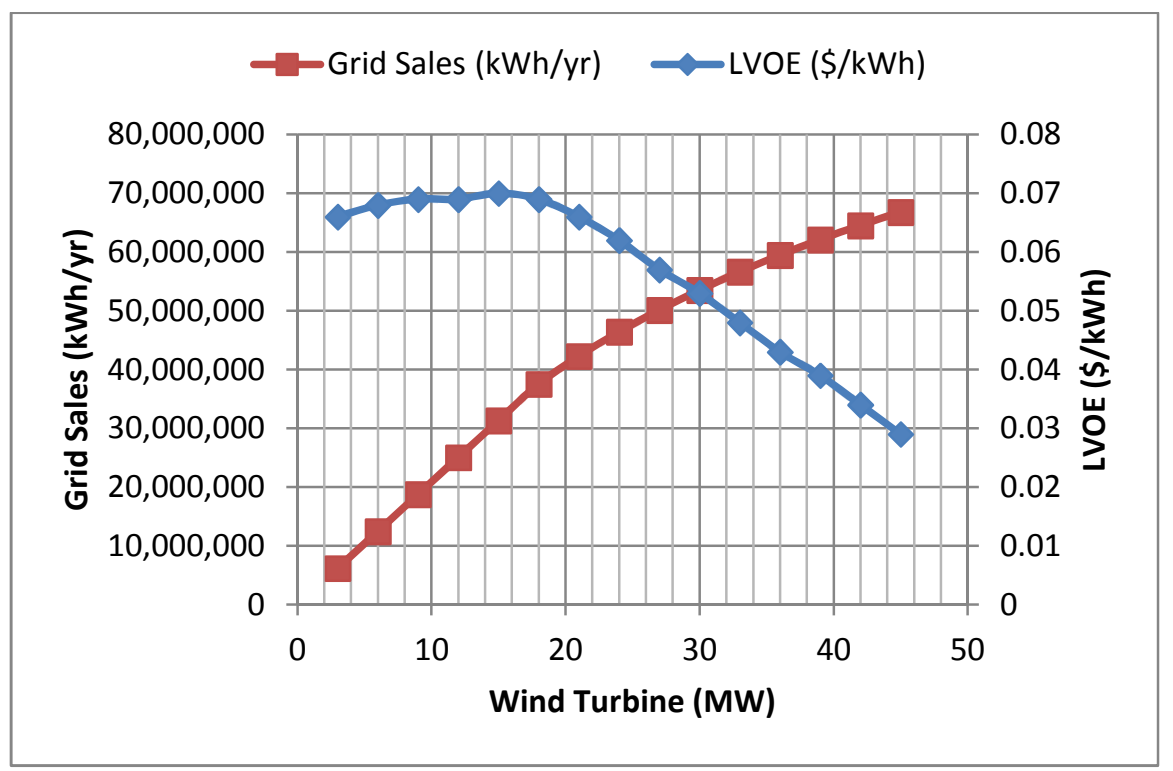

Fig 25: Techno-Economic Analysis Showing Grid Sales and LVOE for WSS Distributed Generation for Benin City

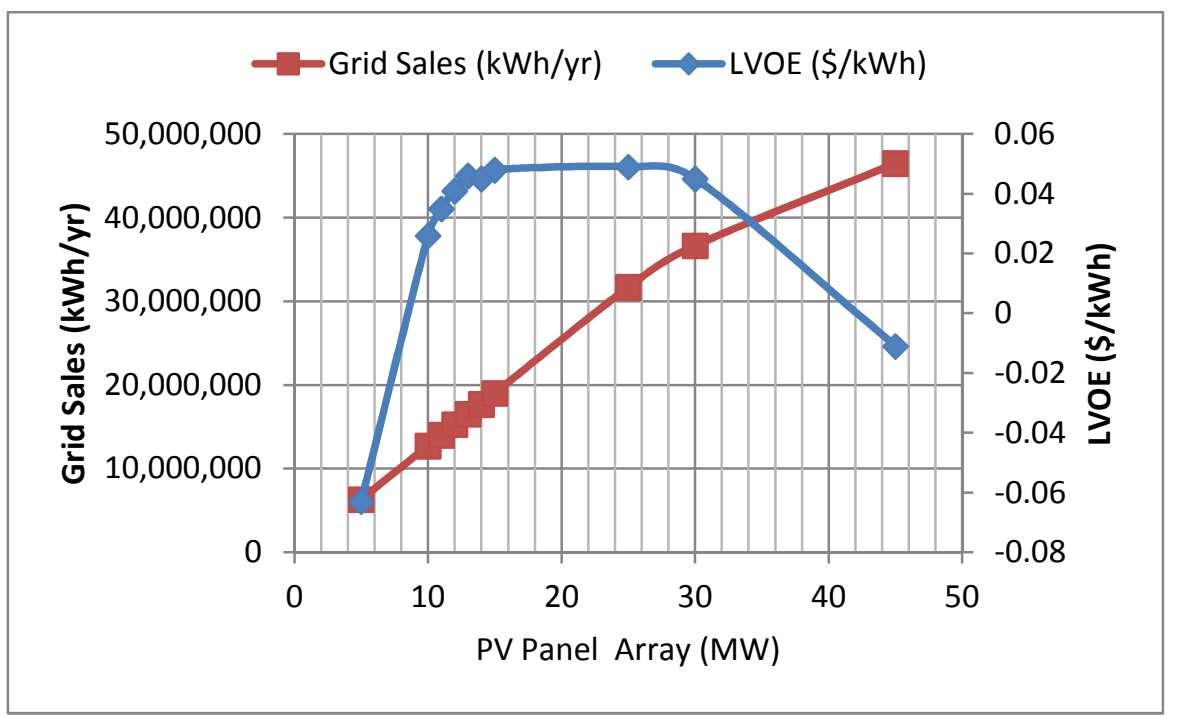
Fig 26: Techno-Economic Analysis Showing Grid Sales and LVOE for PSS Distributed
Generation for Benin City

\section{Conclusion}

Renewable energy systems covering PV and wind energy resources were assessed for six meteorological locations within the six geopolitical zones of Nigeria as standalone and in hybrid format for sites in these regions for remote community utilization as well as for distributed generation. Since the DSS is the only conventional means of generating power for these remote locations, due to their isolation from the national grid, it was taken as the basis of comparison. This study showed that the most economically feasible substitute for power generation at these rural communities of 200 homes in Jos (NC), Maiduguri (NE), Kano (NW), Iseyin (SW), Enugu (SE), and Benin City (SS) is the wind standalone system. This is in comparison to the present cost of grid electricity, at a cost of about $\$ 0.09 / \mathrm{kWh}$, which makes the WSS, PSS and hybrid system quite competitive. Consequently, RE systems of PV and wind 
should become a priority for government in providing clean and non-depleting renewable energy to the rural poor so as to reduce the level of energy poverty in these communities. This will help meet the millennium development goals (MDG's), as these goals are notably hinged on tolerable access to energy. This venture may also serve as a profitable business enterprise for socially responsible businesses if they take advantage of the provision made by government for embedded generation in Nigeria. Grid sales were discovered to range between 29,431,030 $\mathrm{kWh}$ per year to $103,477,904 \mathrm{kWh}$ per year achievable from a 25MW Solar panel and 18MW wind turbine in Iseyin and Jos respectively. Therefore, the private sector can take advantage of this, while also aiding the growth and development of the rural populace through the instrumentality of adequate supply of energy to boost the socio-economic well-being of rural dwellers, which in no little way will help drive the attainment of the MDGs.

\section{References}

1. Abatcha, H. G., Jumba, A. M.Y. \& Maijama, L. (2011) 'Design and Simulation of a Hybrid PV/FUEL Cell Energy System,' Continental Journal of Engineering Sciences, Vol. 6 (1): pp.37-45.

2.Adekoya L.O.; Adewale A.A. (1992) "Wind energy potential of Nigeria," Renewable Energy, 2(1): pp.35-39.

3.Agajelu, B. O., Ekwueme, O. G., Obuka, N. S. P. \& Ikwu, G. O. R. (2013) "Life Cycle Cost Analysis of a Diesel/Photovoltaic Hybrid Power Generating System," Industrial Engineering Letters ISSN 2224-6096 (Paper) ISSN 2225-0581 (online), Vol.3, No.1, Reprinted pp.1-1.

4.Ajayi, 0.0. (2010) "The Potential for Wind Energy in Nigeria," Wind Engineering 34(3): 303-311.

5.Ajayi, 0.0. (2013) "Sustainable Energy Development and Environmental Protection: Implication for Selected States in West Africa," Renewable and Sustainable Energy Reviews: 26, 532 - 539.
6.Ajayi, 0.0. \& Ajayi, O.0. (2013) “Nigeria's Energy Policy: Inferences, Analysis and Legal Ethics towards RE Development," Energy Policy: 60, 61-67.

7.Ajayi, 0.0. Fagbenle, R.O. \& Katende, J. (2011) 'Wind Profile Characteristics and Econometric Analysis of Wind Power Generation of a Site in Sokoto State, Nigeria,' Energy Science and Technology, 1 (2), 54-66.

8.Ajayi, 0. O., Fagbenle, R. O., Katende, J. \& Okeniyi, J. 0. (2011) "Availability of Wind Energy Resource Potential for Power Generation at Jos, Nigeria," Front Energy, 5(4), 376-385.

9.Ajayi, 0. O., Fagbenle, R. O.; Katende, J., Okeniyi, J. O. \& Omotosho, O.A. (2010) "Wind Energy Potential for Power Generation of a Local Site in Gusau, Nigeria," International Journal of Energy for a Clean Environment, 11(1-4), 99-116.

10.Ajayi, O.O., Ohijeagbon, O.D., Nwadialo, C.E. \& Olasope, O. (2014) "New Model to Estimate Daily Global Solar Radiation over Nigeria," Sustainable Energy Technologies and Assessments, 5,Pages 28-36.

11.Ajayi, O.O., Ohijeagbin, O.D., Ajanaku, K.O., Aasa, S.A. \& Omotosho, O.A. (2014) "Techno-Economic Assessment of Renewable Electricity for Rural Electrification and IT Applications in Selected Sites Across the Geopolitical Zones of Nigeria," Proceedings of the $23^{\text {rd }}$ International Business Information Management Association Conference (23 ${ }^{\text {rd }}$ IBIMA) on Vision 2020: Sustainable Growth, Economic Development, and Global Competitiveness, Valencia, Spain 13-14, May 2014, pp 2216 - 2247.

12.Akella A.K., Sharma M.P. \& Saini R. P. (2007) "In: Optimum Utilization of Renewable Energy Sources in a Remote Area," Renewable and Sustainable Energy Reviews, 11, pp. 894-908.

13.Bayod-Rujula, A. A. (2009) "Future Development of the Electricity Systems with Distributed Generation," Energy, 377-383. 
14.Branker, K., Pathak, M. J. M. \& Pearce, J. M. (2011) "A Review of Solar Photovoltaic Levelised Cost of Electricity:," Renewable and Sustainable Energy Reviews, 15, 44704482.

15.Chineke, T. C. \& Igwiro, E.C. (2008) 'Urban and Rural Electrification: Enhancing the Energy Sector in Nigeria Using Photovoltaic Technology,' African Journal Science and Technology, Vol. 9, No. 1, pp. 102 $-108$.

16.Clark II, W. W. \& Eisenberg, L. (2008) "Agile Sustainable Communities: On-Site Renewable Energy Generation," Utilities Policy, 262-274.

17.Clean Energy Project Analysis, RETScreen Engineering \& Cases Textbook,' (2005) pp 91-116,173-216,316, Third Edition September 2005. Minister of Natural Resources Canada 2001-2005.

18.Duffie, J. A. and Beckman, W. A. (1991) "Solar Engineering of Thermal Processes 2nd ed.," Wiley, New York.

19.Energy For All - Financing access for the poor (2011). 'Special Early Excerpt of the World Energy Outlook 2011,' The International Energy Agency (IEA), pp. 12.

20.Ettah, E. B., Udoimuk, A. B., Obiefuna, J. N. \& Opara, F. E. (2012) "The Effect of Relative Humidity on the Efficiency of Solar Panels in Calabar, Nigeria," Universal Journal of Management and Social Sciences, Vol. 2, No.3.

21.Evans, D.L. (1981) "Simplified Method for Predicting Photovoltaic Array Output," Solar Energy, 27, 6, 555-560.

22.Fagbenle, R.O. \& Karayiannis, T.G. (1994) "On the wind energy resources of Nigeria," International Journal of Energy research, 18(5):pp. 493-508.

23.Fagbenle, R.O. Katende, J. Ajayi, 0.0. \& Okeniyi, J.O. (2011) "Assessment of Wind Energy Potential of Two Sites in North-East, Nigeria," Renewable Energy, 36, 1277-1283.

24.Fesharaki, V. J., Dehghani, M. \& Fesharaki, J. J. (2011) "The Effect of Temperature on
Photovoltaic Cell Efficiency," Proceedings of the 1st International Conference on Emerging Trends in Energy ConservationETEC Tehran, Tehran, Iran, 20-21 November 2011, pp. 1-5.

25.General Wattage Chart [Online], [Retrieved, 24th June, 2013], http://powersurvival.com/info.htm

26.Gupta, A., Saini, R.P., \& Sharma, M.P. (2010) In: "Steady-State Modelling of Hybrid Energy System for off Grid Electrification of Cluster of Villages," Renewable Energy, Vol. 35, pp. 520-535.

27.Hiester, T.R. \& Pennell, W.T. (1981) 'The Siting Handbook for Large Wind Energy Systems,' Wind Books, New York, NY, USA.

28.HOMER Software [Online], [Retrieved, 18th March, 2013], http://homerenergy.com/

29.Hontoria, L., Aguilera, J. \& Zufiria, P. (2005) "A New Approach for Sizing Stand Alone Photovoltaic Systems Based in Neural Networks," Solar Energy 78, 313-319. pp. 135

30.How Much Electricity Do Household Items Use? [Online], [Retrieved, 24th June, 2013], http://michaelbluejay.com/electricit y/howmuch.html

31.Hund, T. (2009) 'Large Format Carbon Enhanced VRLA Battery Test Results,' EESAT-2009, Seattle, Washington.

32.Hunt, G.(2009) 'Achievements of an ABSOLYTE Valve Regulated Lead-Acid Battery Operating in a Utility Battery Energy Storage System (BEES) for 12 Years,' EESAT-2009, Seattle Washington.

33.Ipakchi, A. \& Albuyeh, F. (2009 "Grid of the Future," IEEE Power \& Energy Magazine 7, no. 2): 52-62;

34.Kaabeche, A., Belhamel, M. \& Ibtiouen, R. (2011) "Sizing Optimization of GridIndependent Hybrid Photovoltaic/Wind Power Generation System," Energy Vol. 36, pp.1214-1222 
35.Kanase-Patil A.B. Saini R.P. \& Sharma M.P. (2010) "Integrated Renewable Energy Systems for off Grid Rural Electrification of Remote Area," Renewable Energy, Vol. 35, pp. 1342-1349.

36.Khatib, T., Mohamed, A. \& Sopian, K. (2013) "A Review of Photovoltaic Systems Size Optimization Techniques," Solar Energy Research Institute: Renewable and Sustainable Energy Reviews, Volume 22, Pages 454-465.

37.Lambert M., Gilman P. \& Lilienthal P. (2006) "Micropower System Modeling with HOMER," chap. 15, John Wiley \& Sons, Inc.

38.Lorenz, P., Pinner, D. \& Seitz, T. (2008) "The Economics of Solar Power," pp.1-10.

39.Mamo, X. Mallet, S. ; Coste, T. and Grenard, S. (2009) 'Distribution Automation: The Cornerstone for Smart Grid Development Strategy,' presented at the IEEE Power \& Energy Society General Meeting, Calgary, Canada, July 26-30, 2009.

40.Manwell, J.F. \& McGowan, J. G. (1993) "Lead Acid Battery Storage Model for Hybrid Energy Systems," Solar Energy, Vol. 50, pp. 399-405

41.Markvart, T. (1996) "Sizing of Hybrid PVWind Energy Systems," Solar Energy Vol. 59, pp: 277-281.

42.Mbakwe, S. N. \& Iqbal, M. T.; (2011) 'Amy Hsiao: Design of a $1.5 \mathrm{~kW}$ Hybrid Wind / Photovoltaic Power System for a Telecoms Base Station in Remote Location of Benin City,' Nigeria. Pg 1-7.

43.Meier, P.; Tuntivate, V.; Barnes, D.F.; Bogach, S.V.; Farchy, D. (2010) "Peru: National Survey of Rural Household Energy Use," Energy and Poverty: Special Report," The International Bank for Reconstruction and Development (The World Bank Group), pp. $20,23$.

44.'Multi-Year Tariff Order for the determination of the cost of Electricity Generation,' (2011)- Nigerian Electricity Regulatory Commission, period 1st June 2012 to 31st May 2017, pp.1-37.
45.National Energy Policy (2003) 'The Federal Republic of Nigeria- The Presidency,' Energy Commission of Nigeria, pp. 12-13.

46.Neha Sengupta, Kaushik Das, T.S. Jayram, Deva P. Seetharam (2012) 'Optimal Allocation of Land Area for a Hybrid Solar Wind Power Plant IBM Research' India pp.17

47.Nwosu, C., Uchenna, U. C. \& Madueme, T. (2012) "Wind-Solar Hybrid Power System for Rural Applications in the South Eastern States of Nigeria," Journal of Electronics, Communication and Instrumentation Engineering Research: 2(2), 304-316.

48.Ohijeagbon, O.D. \& Ajayi, O.O. (2014) "Potential and Economic Viability of Standalone Hybrid Systems for a Rural Community of Sokoto, North-west Nigeria," Frontiers in Energy (Springer), DOI 10.1007/s11708-014-0304-z

49.0hijeagbon, O.D. \& Ajayi, O.O. (2015) "Solar Regime and LVOE of PV Embedded Generation Systems in Nigeria, "Renewable Energy 78 (2015) 226-235.

50.0mubo-Pepple, V. B., Tamunoberetonari, I.7 Briggs-Kamara, M. A. (2013) "Influence of Meteorological Parameters on the Efficiency of Photovoltaic Module I Some Cities in the Niger Delta of Nigeria," Journal of Asian Scientific Research, 3(1):107-113.

51.Onyebuchi E.I. (1989) "Alternative Energy Strategies for the Developing World's Domestic Use: A Case Study of Nigerian Household's Final Use Patterns and Preferences," The Energy Journal, 10(3):121-138,

52.0verview of the NERC Regulations on Embedded Generation \& Independent Electricity Distribution Networks, (2012), [Online], [Retrieved, 2nd July, 2013], http://www.businessdayonline.com/NG/in dex.php/law/legal-culture/38733overview-of-the-nerc-regulations-onembedded-generation-a-independentelectricity-distribution-networks

53.Owonubi, O., Bammeke, G., Adelakun, A., Onwah, E., Solanke, A., Equere, U., \& Oyegunle, O. 'Meeting the Power Target- 
Executive Summary,' 2009-08-28, (C) 2009 Vetiva Capital Management Limited. All rights reserved. [Available online, https://www.google.com.ng/url?sa=t\&rct=j $\& \mathrm{q}=\&$ esrc $=\mathrm{s} \&$ source $=$ web $\& \mathrm{~cd}=1 \& \mathrm{cad}=\mathrm{rja} \&$ uact $=8 \& v e d=0$ CBwQFjAA\&url=http $\% 3 \mathrm{~A} \% 2$ F\%2Fwww.proshareng.com $\% 2$ Fnews $\% 2 F d$ ownload.php\%3Fitem\%3DPowerSectorUpd ateMeeting\%2BthePowerTarget.pdf\&ei=2L TYVJvGGcS4UfSrhKgJ\&usg=AFQjCNGQ_HqiB gyGiLnvj_FIIrbu8tTbyw\&bvm=bv.85464276 ,d.d24, retrieved on 09/02/15.]

54.Promoting Renewable Energy and Energy Efficiency in Nigeria (2007) 'The Report of a one-day Conference by Community Research and Development Centre (CREDC),' pp.1-35

55.Rajoriya, E. F (2010) "Sustainable Energy Generation Using Hybrid Energy System for Remote Hilly Rural Area in India," International Journal of Sustainable Engineering, pp.1-9.

56.Renewables Global Status Report, (2014): REN21 Renewable Energy Policy Network for the 21st Century. Available online,[http://www.ren21.net/Portals/0/d ocuments/Resources/GSR/2014/GSR2014_ full\%20report_low\%20res.pdf, retrieved on 09/02/15]

$\begin{array}{lrr}\text { 57.RETScreen } & 4 & \text { Software: } \\ \text { The RETScreen Clean } & \text { Energy } & \text { Project }\end{array}$ Analysis Software - Natural Resources Canada [Online], [Retrieved, 18th March, 2013],

http://www.retscreen.net/ang/home.php

58.Rogers, J. C., Simmons, E. A., Convery, I., \& Weatherall, A. (2008) "Public Perceptions of Opportunities for Community-Based Renewable Energy Projects," Energy Policy, 4217-4226

59.Setiawan, A. A., Zhao, Y. \& Nayar, C. V (2009) "Design, Economic Analysis and Environmental Considerations of Mini-Grid Hybrid Power System with Reverse Osmosis Desalination Plant for Remote Areas," Renewable Energy, Vol. 34, pp. 374-383.

60.Shen, W. X. (2009) “Optimally Sizing of Solar Array and Battery in A Standalone Photovoltaic System in Malaysia," Renewable Energy, vol. 34, no. 1, pp. 348-
352 ,

61.Skoplaki, E. \& Palyvos, J. A. (2009) “On the Temperature Dependence of Photovoltaic Module Electrical Performance: A Review of Efficiency/Power Correlations," Solar Energy (2009), 83, 614624.

62.Summary for Policy Makers: Renewable Power Generation Costs,' (2012). International Renewable Energy Agency (IRENA), pp. 1-11

63.Thomas, D. Hund, Gonzalez, S. \& Barrett, K. (2010) 'Grid-Tied PV System Energy Smoothing, Sandia National Laboratories,' PO Box 5800, Albuquerque, New Mexico, USA, pp.1-5

64.Walker, G. (2008) "What are the Barriers and Incentives for Community-Owned Means of Energy Production And Use?," Energy Policy, 4401-4405.

65.Wustenhagen, R., Wolsink, M., \& Burer, M. J. (2007) "Social Acceptance of Renewable Energy Innovation: An Introduction to the Concept," Energy Policy, 2683-2691.

66.Zainuddin,A., Shaari, S., Omar, A. M., Zain,Z. Md., Soumin, J. \& Surat, Z. (2009) "Preliminary Investigations on the Effect of Humidity on the Reception of Visible Solar Radiation and the Effect of Humidity and Wind Speed on PV Module Output," AIP Conference Proceedings,Volume 1250, pp. 55-58.

67.Zhou, W., Lou, Z., Li, Z., Lu, L. \& Yang, H. (2010) "Applied Energy journal Applied Energy”, Vol. 87, pp. 380-389. 